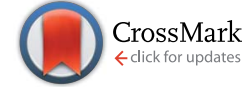

Cite this: J. Mater. Chem. B, 2014, 2, 6953

\title{
DNA adsorbed on hydroxyapatite surfaces $\uparrow$
}

\author{
Luis J. del Valle,,$^{\mathrm{a}}$ Oscar Bertran, $\hat{+}^{\mathrm{b}}$ Gustavo Chaves, ${ }^{a}$ Guillermo Revilla-López, ${ }^{\mathrm{a}}$ \\ Manuel Rivas, ${ }^{a}$ María T. Casas, ${ }^{a}$ Jordi Casanovas, ${ }^{c}$ Pau Turon, ${ }^{\star d}$ Jordi Puiggali ${ }^{\star a e}$ \\ and Carlos Alemán*ae
}

Hydroxyapatite ( $\mathrm{HAp}$ ) particles with very different surface charges and compositions (i.e. different $\mathrm{Ca} / \mathrm{P}$ and $\mathrm{CO}_{3}{ }^{2-} / \mathrm{PO}_{4}{ }^{3-}$ ratios) have been obtained by varying the experimental conditions used during the chemical precipitation process. The DNA adsorption capacity and protection imparted against the attack of nucleases of HAp particles have been proved to depend on the surface charge while the buffering capacity is affected by the chemical composition. On the basis of both the surface charge and the crystallinity, the predominant planes at the surfaces of HAp particles have been identified. Atomistic molecular dynamics simulations of surfaces constructed with these planes (i.e. (001) and the two terminations of (010)) with the adsorbed B-DNA double helix have been performed to get microscopic understanding of the influence of the mineral in the biomolecule structure and the interaction energies. The results indicate that the DNA secondary structure is perfectly preserved on the (001) surface, this stability being accompanied by an attractive binding energy. In contrast, the (010) surface with $\mathrm{PO}_{4}{ }^{3-}, \mathrm{OH}^{-}$and $\mathrm{Ca}^{2+}$ ions in the termination induces significant local and global deformations in the double helix, repulsive $\mathrm{OH}^{-}(\mathrm{HAp}) \cdots \mathrm{PO}_{4}{ }^{3-}$ (DNA) interactions provoking the desorption of the biomolecule. Finally, although the termination of the (010) surface with $\mathrm{PO}_{4}{ }^{3-}$ and $\mathrm{Ca}^{2+}$ ions also deforms the double helix, it forms very strong attractive interactions with the biomolecule. These binding characteristics are in excellent agreement with the DNA adsorption and protection abilities experimentally determined for the HAp samples. Finally, the surface charge has been found less decisive than the chemical composition in the efficacy of the transfection process.
Received 18th July 2014

Accepted 11th August 2014

DOI: $10.1039 / \mathrm{c} 4 \mathrm{tb} 01184 \mathrm{~h}$

www.rsc.org/MaterialsB in a large number of studies. ${ }^{7-15}$ Furthermore, the formation of HAp can be regulated by DNA, which acts as a template in the process of "biomineralization". ${ }^{16-19}$ This phenomenon is particularly important for biomedical applications requiring the protection of such biomolecules from aggressive environmental conditions. In order to elucidate the role of DNA as a template to promote mineral growth, the biomineralization mechanism has been recently revealed at the atomic level. ${ }^{16-19}$

In very recent studies, we examined the encapsulation of DNA into HAp using computer simulation and experimental techniques. ${ }^{16,19}$ Classical molecular dynamics (MD) simulations of inorganic $\mathrm{Ca}^{2+}, \mathrm{PO}_{4}{ }^{3-}$ and $\mathrm{OH}^{-}$aqueous solutions in the presence and absence of DNA showed that the biomolecule acts as a template for the nucleation and growth of HAp. Simulations in the absence of DNA revealed the formation of multiple calcium phosphate clusters, which subsequently transform into nucleation centers for the formation of HAp. In contrast, simulations in the presence of the biomolecule revealed that calcium phosphate clusters are formed surrounding the DNA backbone, the phosphate groups of the biomolecule acting as a very large nucleus for the growth of HAp. In summary, MD simulations clearly indicated that DNA does not inhibit, as it has been suggested before, ${ }^{20}$ but instead promotes mineral growth. These conditions were experimentally applied in the 
laboratory to create nanoparticles of spherical shape (diameter $\approx 20 \mathrm{~nm}$ ) and nanocrystals (nanorods with a width of $\sim 20 \mathrm{~nm}$ ) with DNA inside. The encapsulation of DNA into both nanospheres and nanocrystals was unambiguously determined by different techniques after all superficially adsorbed DNA was appropriately removed (i.e. by digestion with deoxyribonuclease).

HAp nanoparticles are also suitable as gene delivery systems for the transfection of cells with nucleic acids. ${ }^{21-24}$ This strategy can be used to turn on (transfection, DNA) or to turn off (gene silencing, siRNA) the production of a specific protein. ${ }^{25,26}$ Furthermore, HAp binding ability may confer protection to DNA from chemical and enzymatic degradation. Indeed, the shielding effect to protect nucleic acids has been proved for different mineral surfaces. ${ }^{27-30}$ In addition, HAp columns have been used as an efficient binding method for the sequestering of DNA. ${ }^{31}$ The influence of the binding affinity of HAp surfaces for DNA on the stability of the biomolecule has been recently assessed by Brundin et al., ${ }^{32}$ with the results indicating that DNA-bound HAp (DNA-HAp) is more resistant to decay by ambient environmental factors and less susceptible to degradation by serum and nucleases.

Despite the potential interest of DNA-HAp complexes, many aspects related to the ability of HAp to bind to DNA remain unknown. In this work we use an approach that combines both experimental and theoretical methodologies, which is similar to that used for the study of biominerals made of DNA embedded into HAp, ${ }^{\mathbf{1 6}, 19}$ to investigate different chemical and microscopic aspects related to the capacity of the mineral to adsorb DNA. For this purpose, HAp particles with different morphologies and surface compositions have been prepared. These HAp particles have been used to investigate the influence of composition and charge surface on the buffering activity, DNA adsorption capability and efficacy to protect adsorbed DNA from nucleases. After this, MD computer simulations using atomistic models have been used to examine at the microscopic level the adsorption of double helix B-DNA at the surfaces identified for experimentally prepared HAp samples. Finally, DNA-HAp complexes have been used to transfect $E$. coli bacteria, results revealing the relative importance of the HAp surface charge and composition in the efficacy of the transfection process.

\section{Methods}

\section{Experimental methods}

Materials. Ammonium phosphate dibasic $\left[\left(\mathrm{NH}_{4}\right)_{2} \mathrm{HPO}_{4}\right.$; purity $\geq 99.0 \%$ ], ammonium hydroxide solution $30 \%\left(\mathrm{NH}_{4} \mathrm{OH}\right.$; purity: $28-30 \%$ ), Luria-Bertani (LB) medium (purity $\geq 96 \%$ ), ampicillin $\left(\mathrm{C}_{16} \mathrm{H}_{18} \mathrm{~N}_{3} \mathrm{NaO}_{4} \mathrm{~S}\right.$; purity: 96-100\%) and deoxyribonuclease from bovine pancreas (DNaseI enzyme; purity: protein $\geq 85 \%, \geq 400$ Kunitz units per mg protein) were purchased from Sigma-Aldrich (St. Louis, USA). Calcium nitrate $\left[\mathrm{Ca}\left(\mathrm{NO}_{3}\right)_{2}\right.$; purity $\geq 99.0 \%$, hydrochloric acid solution $37 \%(\mathrm{HCl}$; purity: $36.5-38.0 \%)$ and sodium chloride ( $\mathrm{NaCl}$; purity $\geq 99.0 \%)$ were purchased from Panreac (Barcelona, Spain). Ethanol $\left(\mathrm{C}_{2} \mathrm{H}_{5} \mathrm{OH}\right.$; purity $\geq 99.5 \%$ ) was obtained from Scharlab (Barcelona, Spain). The gel loading buffer (100 bp DNA ladder, $0.1 \mu \mathrm{g} \mu \mathrm{L}^{-1}$; purity $\geq$
99.5\%) and competent E. coli DH5 $\alpha$ bacteria were obtained from Invitrogen (Carlsbad, USA). Sal I (10 U $\mu \mathrm{L}^{-1}$; SalI enzyme; purity $\geq 99.5 \%$ ) and SuRE/Cut buffer $\mathrm{H}$ for restriction enzymes (purity $\geq 99.5 \%$ ) were purchased from Roche (Indianapolis, USA). The QIAprep Spin miniprep kit was purchased from QIAGEN (Manchester, UK). Ethidium bromide $\left(\mathrm{C}_{21} \mathrm{H}_{20} \mathrm{BrN}_{3}\right.$; purity $\geq 99.0 \%$ ) and tris-borate-EDTA (TBE) buffer (89 mM tris, $89 \mathrm{mM}$ boric acid, $2 \mathrm{mM}$ EDTA; purity $\geq 99.0 \%$ ) solutions as well as commercial hydroxyapatite $\left[\mathrm{Ca}_{5}\left(\mathrm{PO}_{4}\right)_{3}(\mathrm{OH})\right.$; purity $\geq$ 99.0\%] were obtained from Bio-Rad (Hercules, USA). All products were used as received.

Synthesis of hydroxyapatites. HAp particles with different morphologies, which have been labeled as HAp\#, were synthesized. More specifically, sheet crystals (HAp2), amorphous nanospheres (HAp3) and fusiform rods (HAp4) were prepared, whereas commercial HAp Bio-Gel ${ }^{\circledR}$ HTP Gel from BIO-RAD (HAp1) was used as the control in all assays.

Samples HAp2-HAp4 were prepared using the same procedure but under different experimental conditions. In all cases solutions of $\left(\mathrm{NH}_{4}\right)_{2} \mathrm{HPO}_{4}$ in deionized water were added dropwise $\left(2 \mathrm{~mL} \mathrm{~min}{ }^{-1}\right)$ or quickly to $\mathrm{Ca}\left(\mathrm{NO}_{3}\right)_{2}$ ethanol or water solutions. The reagent concentrations were adjusted to get a $\mathrm{Ca} /$ $\mathrm{P}$ ratio of 1.67. The $\mathrm{pH}$ of the reaction, which was different for each sample, was adjusted with ammonia $30 \% \mathrm{w} / \mathrm{v}$ solution. All samples were mixed $1 \mathrm{~h}$ by agitation (400 rpm), and the subsequent aging step was carried out under hydrothermal or non-hydrothermal conditions. The specific experimental conditions used for the preparation of each sample are detailed in Table S1.† After preparation, the particles were recovered from the mother liquor by centrifugation, and all samples were washed twice with de-ionized water and a 60/40 v/v mixture of ethanol-water. White powder was obtained after freeze-drying.

Morphological characterization. Transmission electron microscopy (TEM) and scanning electron microscopy (SEM) were used for the morphological characterization of the different HAp samples. TEM images were obtained using a Philips TECNAI 10 electron microscope operating at $80 \mathrm{kV}$ for a bright field mode. Micrographs were taken with an SIS MegaView II digital camera. Particles were deposited on carboncoated grids.

SEM studies were carried out using a Focused Ion Beam Zeiss Neon40 microscope operating at $5 \mathrm{kV}$, equipped with an energy dispersive X-ray (EDX) spectroscopy system. Samples were deposited on a silicon disc mounted with silver paint on pin stubs of aluminum, and sputter-coated with a thin layer of carbon to prevent sample charging problems.

Fourier transform infrared (FTIR) spectroscopy. Infrared absorption spectra were recorded from powder samples with a Fourier Transform FTIR 4100 Jasco spectrometer in the 1800$700 \mathrm{~cm}^{-1}$ range. Specac model MKII Golden Gate attenuated total reflection (ATR) equipment with a heated Diamond ATR Top-Plate was used.

X-Ray diffraction. Crystallinity was studied by wide angle X-ray scattering (WAXS). Patterns were acquired using a Bruker D8 Advance model with $\mathrm{Cu} \mathrm{K}_{\alpha}$ radiation $(\lambda=0.1542 \mathrm{~nm})$ and geometry of Bragg-Brentano, theta-2-theta. A one-dimensional Lynx Eye detector was employed. Samples were run at $40 \mathrm{kV}$ and 
$40 \mathrm{~mA}$, with a 2-theta range of 10-60, measurement steps of $0.02^{\circ}$, and time per step of 2-8 s. Diffraction profiles were processed using PeakFit v4 software (Jandel Scientific Software) and the graphical representation was performed using OriginPro v8 software (OriginLab Corporation, USA).

The crystallite size $(L)$ in the direction representative to the (211) planes of HAp1-HAp4 samples was derived from the X-ray diffraction line broadening measurement using the Scherrer equation: ${ }^{33}$

$$
L=\frac{0.9 \lambda}{\beta \cos \theta}
$$

where $\lambda$ is the wavelength $\left(\mathrm{CuK}_{\alpha}\right), \beta$ is the full width at half maximum height of the (211) line, $\theta$ is the diffraction angle and 0.9 is the shape factor.

The crystallinity $\left(\chi_{\mathrm{c}}\right)$ was obtained using the following equation: ${ }^{34}$

$$
\chi_{\mathrm{c}}=1-\frac{V_{112 / 300}}{I_{300}}
$$

where $I_{300}$ is the intensity of the (300) reflection and $V_{112 / 300}$ is the intensity of the hollow between the (112) and (300) reflections, which disappears in non-crystalline samples.

Zeta potential. Measurements were performed on a Malvern Zetasizer Nano-ZS (Malvern Instruments Ltd., Worcestershire, UK). The zeta potential was obtained by determining the electrophoretic mobility of the samples at $25^{\circ} \mathrm{C}$, using laser Doppler velocimetry. Each measurement was conducted in a capillary cell (DTS0012). HAp samples were re-suspended in ultrapure milli-Q water (Millipore) at $0.5 \mathrm{mg} \mathrm{mL}^{-1}$ and, subsequently, sonicated for $5 \mathrm{~min}$ in a water bath. Each experiment was repeated five times and the average values are presented in this work.

HAp protonation assay. The protonation ability of the different HAp samples was determined using the following procedure. HAp particles suspended in milli-Q water $(1 \mathrm{mg}$ $\mathrm{mL}^{-1}$ ) were protonated by adding an aqueous solution of 100 $\mathrm{mM} \mathrm{HCl}$ and $50 \mathrm{mM} \mathrm{NaCl}$ up to $\mathrm{pH} \approx 3$. Samples $(5 \mathrm{~mL})$ were kept in a vial under continuous stirring, the $\mathrm{pH}$ values being determined every minute at $20{ }^{\circ} \mathrm{C}$ using a pH-meter. The total time taken for this assay was 15 minutes.

Formation of DNA-HAp complexes. Aqueous suspensions of HAp particles $\left(5 \mathrm{mg} \mathrm{mL}{ }^{-1}\right.$ ) were prepared and subsequently sonicated to enhance the dispersion. DNA-HAp complexes were formed by adding $2.5 \mu \mathrm{L}$ of plasmid pMT4 $\left(0.4 \mu \mathrm{g} \mathrm{mL}^{-1}\right)$ to the volume of HAp suspension necessary to reach the following $\mathrm{w} / \mathrm{w}$ DNA : HAp ratios: $1: 0 \quad 1: 10,1: 50,1: 100$ and $1: 250$. DNA : HAp mixtures were incubated for $90 \mathrm{~min}$ at $37^{\circ} \mathrm{C}$ and 200 $\mathrm{rpm}$, shaking them with a vortex every $30 \mathrm{~min}$. Complexes were separated from the solution by centrifugation at $10000 \mathrm{rpm}$ for $10 \mathrm{~min}$. Sediments were re-suspended in $10 \mu \mathrm{L}$ of sterile water.

The formation of DNA-HAp complexes was detected using agarose gel electrophoresis. For this purpose, gel loading buffer $6 \times(2 \mu \mathrm{L})$ was added to the complex solutions $(10 \mu \mathrm{L})$ and then loaded in an agarose gel of $1 \%(\mathrm{w} / \mathrm{v})$ containing ethidium bromide (EtBr, $0.5 \mu \mathrm{g} \mathrm{mL} \mathrm{m}^{-1}$ of the gel) in $1 \times$ tris-borate-EDTA buffer (TBE).
DNA adsorption quantification. For quantification of adsorbed DNA on complexes obtained from DNA : HAp mixtures with $1: 100$ and $1: 250$ ratios, particles were separated by centrifugation and subsequently re-suspended on $1 \mathrm{~mL}$ of deionized water. An UV-3600 (Shimadzu) UV-Vis/NIR spectrophotometer controlled using UVProbe 2.31 software was used to record the UV-Vis spectra of DNA-HAp complexes at room temperature, in the 200-400 $\mathrm{nm}$ range, with a bandwidth of $0.2 \mathrm{~nm}$ and a scan speed of $600 \mathrm{~nm} \mathrm{~min}^{-1}$. Samples were homogenized by pipetting before recording the spectra. In order to evaluate the denaturalization of DNA adsorbed on the HAp particles, spectra were also recorded for samples heated at $94^{\circ} \mathrm{C}$.

Nuclease digestion. DNA-HAp complexes formed using $1: 100$ and 1 : 250 mixtures were prepared as described before. After separating the particles by centrifugation, $9 \mu \mathrm{L}$ of sterile water and $1 \mu \mathrm{L}$ of enzyme DNaseI were added to each precipitate and digested for $1 \mathrm{~h}$ at $37^{\circ} \mathrm{C}$ (200 rpm). Then, each sample was mixed with $2 \mu \mathrm{L}$ of gel loading buffer $6 \times$. The resulting volume was loaded in an agarose gel of $1 \%(\mathrm{w} / \mathrm{v})$ for electrophoresis.

The same procedure was applied for digestion with SalI enzyme but using SuRE/Cut buffer $\mathrm{H}$ for restriction enzymes instead of water.

Bacterial transfection. DNA-HAp complexes derived from $1: 250 \mathrm{w} / \mathrm{w}$ mixtures were separated by centrifugation and resuspended in $10 \mu \mathrm{L}$ of sterile water. Considering the transfection of all DNA bound to HAp as well as the binding efficiencies estimated for each HAp sample, aliquots from 6.8 to $7.7 \mu \mathrm{L}$ of suspensions were added to $10 \mu \mathrm{L}$ of competent $E$. coli $\mathrm{DH} 5 \alpha$ bacteria. Samples were mixed by pipetting, placed on a water bath for $5 \mathrm{~min}$ at $42{ }^{\circ} \mathrm{C}$, and cooled on ice at $4{ }^{\circ} \mathrm{C}$ for 2 min. After that, $200 \mu \mathrm{L}$ of Luria-Bertani (LB) medium were added and samples were left at $37^{\circ} \mathrm{C}$ under agitation for $1 \mathrm{~h}$. $100 \mu \mathrm{L}$ of bacterial suspension was seeded on LB agar plates containing $100 \mu \mathrm{g} \mathrm{mL} \mathrm{m}^{-1}$ of ampicillin. Finally, samples were incubated for $24 \mathrm{~h}$ at $37^{\circ} \mathrm{C}$.

To probe the transfected plasmid integrity, transformed bacterial colonies from LB-ampicillin agar plates were picked up and left to grow in a LB broth containing ampicillin $(100 \mu \mathrm{g}$ $\mathrm{mL}^{-1}$ ). After $24 \mathrm{~h}$ incubation at $37{ }^{\circ} \mathrm{C}$, bacterial colonies were washed with sterile water and pelletized by centrifugation. Purification of DNA was carried out by using the QIAprep ${ }^{\circledR}$ Spin Miniprep kit (QIAGEN). Aliquots of $10 \mu \mathrm{L}$ of bacterial purified DNA were mixed with $2 \mu \mathrm{L}$ of gel loading buffer $6 \times$ and the whole volume was introduced in the well of agarose $1 \%$ electrophoresis gel.

In order to measure the transformed efficiency, bacterial colonies were scratched and washed with $10 \mathrm{~mL}$ of LB media. Samples were homogenized by pipetting and spectra were recorded at $600 \mathrm{~nm}$ using the UV-3600 spectrophotometer mentioned above. A sample of LB media was used as the blank for the analysis.

\section{Computational methods}

Model of DNA molecule and HAp surfaces. The DNA molecule simulated in this work consisted of Dickerson's dodecamer (5'-CGCGAATTCGCG-3'), which is a well-known sequence that 
adopts a B-DNA double helix. ${ }^{35}$ The hexagonal HAp crystal unit cell with $\mathrm{P6}_{3} / m$ geometry $(a=b=9.421 \AA$ 的 $c=6.881 \AA, \alpha=\beta=$ $90^{\circ}$, and $\gamma=120^{\circ}$ ) and the $4 \mathrm{e}$ Wyckoff position occupied by two hydroxyl ions, each with $1 / 2$ occupancy, ${ }^{36}$ was generated and, subsequently, was cleaved to obtain the (001) and (010) surfaces. Following the strategy of de Leeuw and co-workers, ${ }^{37}$ the partial occupation of the hydroxide anions was solved by assigning 1 and 0 occupation values alternatively in the columns parallel to the $c$-direction of the unitary cell. This configuration renders equal orientation for all $\mathrm{OH}^{-}$ions in a column but alternated between columns since this has been reported as the most stable ensemble. ${ }^{38}$ The employed unit cell (44 atoms) was expanded 6 times in the $x$ and $y$ directions, creating a $6 \times 6$ supercell. The two planes considered in this work are (001) and (010), which are the lowest energy facets. ${ }^{37,38}$ The thickness of the supercell in the $z$ axis entailed a 4 layer slab, being equivalent to 3 times the interplanar distance. The (001) facet has only one possible termination, whereas it is not possible to construct a slab of the (010) surface with the same termination at both sides. More specifically, construction of a stable (010) surface, in which the total dipole moment across the slab perpendicular to the surface is zero, leads to sides that differ in the content of $\mathrm{OH}^{-}$and $\mathrm{Ca}^{2+}$ ions. One side, hereafter denoted $\left(010\right.$; $\left.\mathrm{Ca}^{2+}\right)$, only contains $\mathrm{Ca}^{2+}$ and $\mathrm{PO}_{4}{ }^{3-}$ while the other side, denoted $\left(010 ; \mathrm{Ca}^{2+}-\mathrm{OH}^{-}\right)$, involves $\mathrm{Ca}^{2+}, \mathrm{OH}^{-}$and $\mathrm{PO}_{4}{ }^{3-}$. Although $\left(010 ; \mathrm{Ca}^{2+}\right)$ is more stable, the $\left(010 ; \mathrm{Ca}^{2+}-\mathrm{OH}^{-}\right)$ termination was found to be the most favorable for interacting with ionic species because of its greater variation of surface species. ${ }^{37}$ In this work we considered both the $\left(010 ; \mathrm{Ca}^{2+}-\mathrm{OH}^{-}\right)$ and $\left(010 ; \mathrm{Ca}^{2+}\right)$ terminations at the $(010)$ surface. Initially, DNA was placed parallel to the surfaces at $5 \AA$ as the average distance between its most outer groups and the atoms in the surface. Charge neutralization was performed with the addition of $\mathrm{Na}^{+}$ counterions. Afterwards, both surfaces were solvated in the $z$ direction with 17756 and 24029 water molecules for (001) and the two (010) terminations, respectively.

All energy minimizations and MD simulations were performed using the NAMD 2.6 code. ${ }^{39}$ The potential energy was computed using the Amber force-field. ${ }^{40}$ All force-field parameters for DNA as well as the phosphate and hydroxyl groups were extracted from Amber ff03. ${ }^{41}$ It should be noted that the ff03 parameters are identical to the ff99-SB ${ }^{42}$ ones for nucleic acids, phosphate and hydroxyl groups. Force-field parameters of $\mathrm{Ca}^{2+}$ were extracted from the work reported by Bradbrook et al. ${ }^{43}$ The ability of this set of force-field parameters to reproduce the inorganic...organic interactions found in biominerals was recently proved. ${ }^{16}$ Water molecules were represented using the TIP3P model. ${ }^{\mathbf{4 4}}$

Initially, water and DNA coordinates were optimized through 5000 steps of conjugated gradient algorithm minimization. The resulting coordinates of the two systems underwent $0.5 \mathrm{~ns}$ of NVT molecular dynamics (MD) at $373 \mathrm{~K}$ (Berendsen thermostat $^{45}$ ) with frozen coordinates for DNA and HAp. Final coordinates and velocities of the NVT run were used as input for $0.5 \mathrm{~ns}$ NPT ( $298 \mathrm{~K}, 1$ bar) to equilibrate water density to $1 \mathrm{~g} \mathrm{~cm}^{-3}$ in the volume occupied by the liquid and DNA. The Berendsen thermobarostat $^{45}$ was employed at a constant $x y$ plane area and frozen DNA and mineral slab coordinates. Productive dynamics started from the latter output, only keeping fixed the mineral atoms. Trajectories were $15.1 \mathrm{~ns}$ long, the 0.1 initial ns being discarded as the equilibration. In addition, the DNA double helix and the $20 \mathrm{Na}^{+}$counterions were solvated with 30000 water molecules and the density of the resulting system was equilibrated to $1 \mathrm{~g} \mathrm{~cm}^{-3}$ following the same protocol used for the surface slabs. Productive control dynamics were $15.1 \mathrm{~ns}$ long with a $0.1 \mathrm{~ns}$ equilibration period.

Atom pair distance cut-offs were applied at $16.0 \AA ̊$ to compute the van der Waals interactions. In order to avoid discontinuities in the Lennard-Jones potential, a switch function was applied to allow a continuous decay of the energy when the atom pair distances are larger than $14.0 \AA$. For electrostatic interactions, we computed the non-truncated electrostatic potential through Ewald Summations. ${ }^{45}$ The real space term was determined by the van der Waals cut-off ( $16 \AA$ ), while the reciprocal term was estimated by interpolation of the effective charge into a charge mesh with a grid thickness of 5 points per volume unit, i.e. the Particle-Mesh Ewald (PME) method. ${ }^{46}$ Bond lengths were constrained using the SHAKE algorithm ${ }^{47}$ with a numerical integration step of $1 \mathrm{fs}$. Periodic boundary conditions were applied using the nearest image convention, and the non-bonded pair list was updated every 1000 steps (1 ps).

\section{Results and discussion}

\section{Synthesis and characterization of HAp particles}

HAp particles with different morphologies were synthesized by chemical precipitation (see the Methods section) under the experimental conditions listed in Table S1. $\uparrow$ These conditions differ in the $\mathrm{pH}$ and temperature of the medium, the concentration of $\mathrm{Ca}\left(\mathrm{NO}_{3}\right)_{2}$ in organic or aqueous solvent, and the application or no application of hydrothermal treatment. The morphologies of commercial HAp (HAp1) and the three prepared HAp samples, HAp2-HAp4, which are displayed in Fig. 1, reflect the noticeable influence of each of the different factors examined in this work: $\mathrm{pH}$, temperature of the reaction, solvent used with the reagents, and both hydrothermal and aging conditions. HAp2 (Fig. 1d and e) and HAp4 (Fig. 1h and i) show crystals with very different morphologies (i.e. flower-like and laminar crystals and fusiform rods). HAp3 particles, which were obtained in an extremely alkaline reaction medium $(\mathrm{pH}>11)$ and without hydrothermal treatment, are the only ones with nanospherical morphology (Fig. 1f and g).

Different morphologies were consistent with $\mathrm{Ca} / \mathrm{P}$ ratios that deviate from the value of 1.67 for the stoichiometric cases, which reflects the presence of different faces (i.e. the formula unit of the surface unit cell cannot be expressed as an integer multiple of the formula of the HAp bulk unit cell). Table 1 displays the $\mathrm{Ca} / \mathrm{P}$ ratio for the different HAp particles as measured by EDX spectroscopy. The Ca/P ratio for HAp1 is 1.71 \pm 0.25 , the large deviation of the values being attributed to the coexistence of two different morphologies in such a commercial sample (Fig. 1a-c). HAp2 exhibits a value lower than the stoichiometric ratio $(1.37 \pm 0.07)$, whereas HAp4 shows a higher 


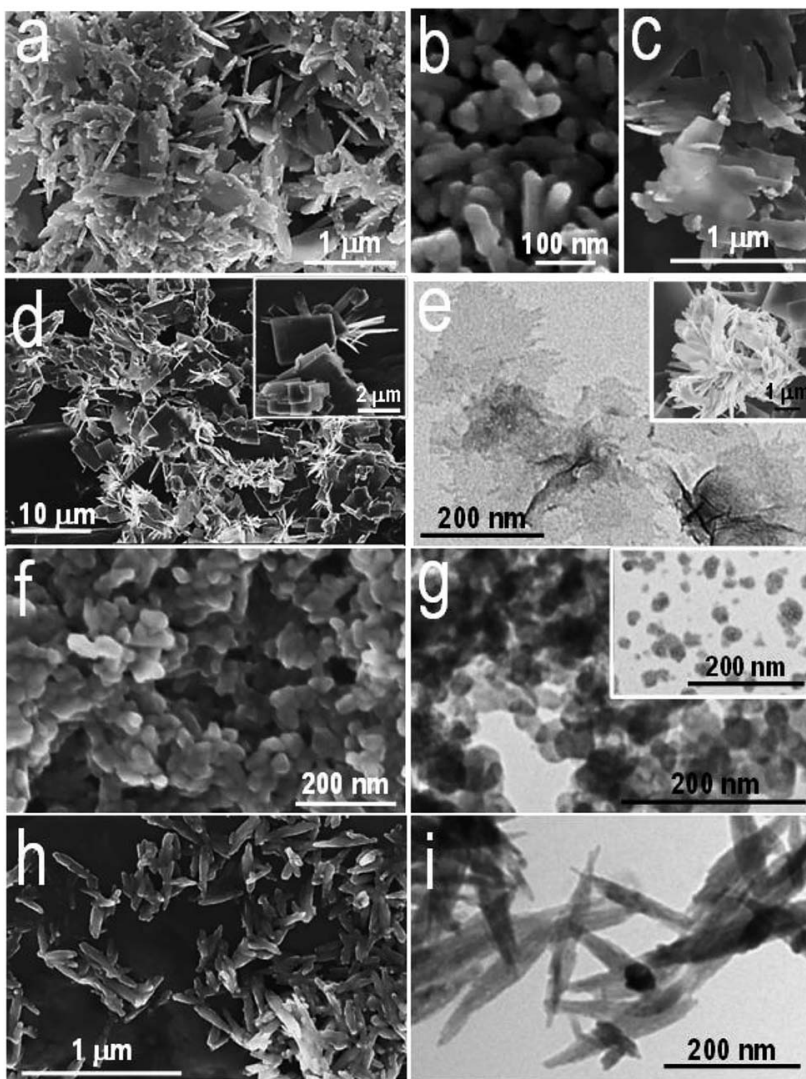

Fig. 1 Morphology of HAp particles studied in this work: HAp1 (a-c), HAp2 (d-e), HAp3 ( $f-g)$, and HAp4 (h-i). HAp1 refers to commercial samples while HAp2-HAp4 correspond to samples prepared in this work by chemical precipitation (see Methods) under the experimental conditions displayed in Table S1.† SEM images: (a)-(d), (f) and (h). TEM images: (e), (g) and (i).

value $(1.94 \pm 0.08)$. Finally, HAp3 showed a stoichiometric $\mathrm{Ca} / \mathrm{P}$ ratio of $1.69 \pm 0.05$.

Table 1 includes the main physical properties (i.e. zeta potential, particle dimensions, surface area, crystallite size and crystallinity) of the four HAp samples studied in this work. The zeta potential values of HAp3 and HAp4 $(\mathrm{ZP}=-1.3 \pm 0.1$ and $+0.6 \pm 0.1 \mathrm{mV}$, respectively) are higher than those of commercial HAp1 $(\mathrm{ZP}=-2.5 \pm 0.2 \mathrm{mV})$, which in turn is higher than that obtained for HAp2 $(\mathrm{ZP}=-3.6 \pm 0.2 \mathrm{mV})$. As the zeta potentials were determined in deionized water, these values should be considered equivalent to the surface charge. These results combined with the crystallinities and $\mathrm{Ca} / \mathrm{P}$ ratios listed in Table 1 suggest that the surfaces of HAp4 and HAp2 crystallites may be dominated by the $\left(010 ; \mathrm{Ca}^{2+}\right)$ and $(010$; $\mathrm{Ca}^{2+}-\mathrm{OH}^{-}$) terminations, respectively, of the (010) plane. Thus, the $\left(010 ; \mathrm{Ca}^{2+}-\mathrm{OH}^{-}\right)$termination, which involves $\mathrm{Ca}^{2+}, \mathrm{OH}^{-}$and $\mathrm{PO}_{4}{ }^{3-}$ at the top, and the $\left(010 ; \mathrm{Ca}^{2+}\right)$ termination, with only $\mathrm{Ca}^{2+}$ and $\mathrm{PO}_{4}{ }^{3-}$ at the top, are consistent with the negative and positive surface charges obtained for HAp2 and HAp4, respectively. The zeta potential of HAp1, which is less negative than that of HAp2, may be attributed to the predominance of the (001) plane at the surface. The (001) plane is the most stable HAp surface ${ }^{48}$ and was identified as the crystal growth plane during the biomineralization of teeth and hard tissues (dentine and enamel). ${ }^{49-52}$ Furthermore, these faces also determine a morphology transformation from needles to plates. ${ }^{52}$ All these features are consistent with the crystalline rods contained in HAp1 samples (Fig. 1a and b), which only show a crystallinity of $50 \pm 4 \%$. Although the association of HAp1, HAp2 and HAp4 to the (001), $\left(010 ; \mathrm{Ca}^{2+}-\mathrm{OH}^{-}\right)$and $\left(010 ; \mathrm{Ca}^{2+}\right)$ surfaces, respectively, is an assumption derived from the zeta potential values and the surface $\mathrm{Ca} / \mathrm{P}$ ratios listed in Table 1 , the results described in the next-subsections are fully consistent with these hypotheses (see below). Finally, the moderately negative zeta potential of HAp3 samples, which are amorphous, results from the non-regular distribution of $\mathrm{Ca}^{2+}, \mathrm{PO}_{4}{ }^{3-}$ and $\mathrm{OH}^{-}$ions. This disordered distribution of ions is fully consistent with the stoichiometric $\mathrm{Ca} / \mathrm{P}$ ratio measured at the surface of HAp3 samples by EDX.

The FTIR spectra of the four studied HAp samples are compared in Fig. 2 while Table $\mathrm{S} 2 \uparrow$ quantifies the characteristic absorption bands by integrating the corresponding areas. The spectra clearly indicate a relationship between the morphology of HAp particles and the environment of phosphate groups. The spectra recorded for HAp1, HAp3 and HAp4 samples show typical $\mathrm{PO}_{4}{ }^{3-}$ bands at the region comprised between 950 and $1200 \mathrm{~cm}^{-1}$, even though quantitative differences are detected, as is clearly evidenced in Table S2. $\dagger$ Thus, the FTIR spectrum of the commercial HAp1 sample shows characteristic vibrational modes of $\mathrm{PO}_{4}{ }^{3-}$ at $\nu_{1}=957 \mathrm{~cm}^{-1}$ and $\nu_{3}=1016$ and $1084 \mathrm{~cm}^{-1}$, the other two samples showing small (red and blue) shifts with respect to such values (i.e. $\left|\Delta \nu_{1}\right| \leq 5 \mathrm{~cm}^{-1}$ and $\left|\Delta \nu_{3}\right| \leq 6 \mathrm{~cm}^{-1}$ ). The spectrum of HAp2 shows very remarkable resolution, presenting high (blue) shifts (i.e. $\Delta \nu_{1} \leq 37 \mathrm{~cm}^{-1}$ and $\left|\Delta \nu_{3}\right| \leq 42$, $41 \mathrm{~cm}^{-1}$ ) in comparison with the rest of the samples, which is consistent with a notorious morphological change and their $\mathrm{Ca} / \mathrm{P}$ ratio.

Table $1 \mathrm{Ca} / \mathrm{P}$ ratio, zeta potential (ZP), particle dimensions ( $w=$ width; $\ell=$ length; $h=$ height; and $R=$ radius), surface area $(S)$, crystallite size $(L)$ and crystallinity $\left(\chi_{c}\right)$ obtained for HAp1-HAp4 particles. Average \pm standard deviation values were derived from 6 independent measures

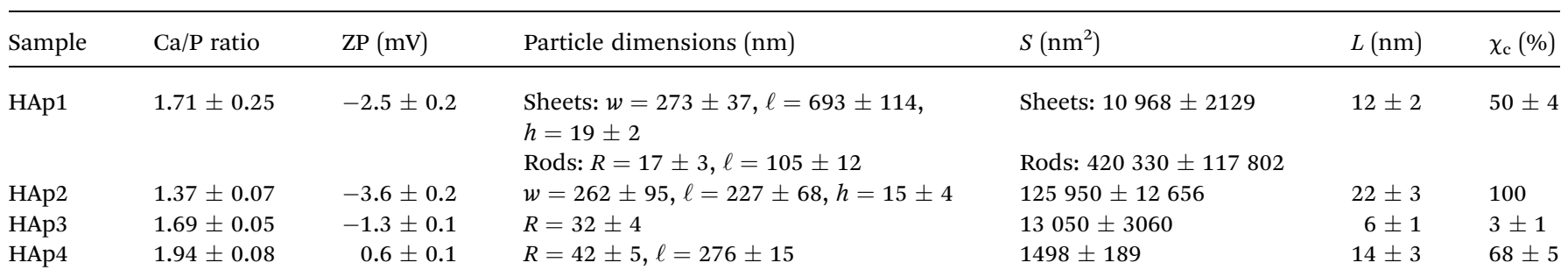




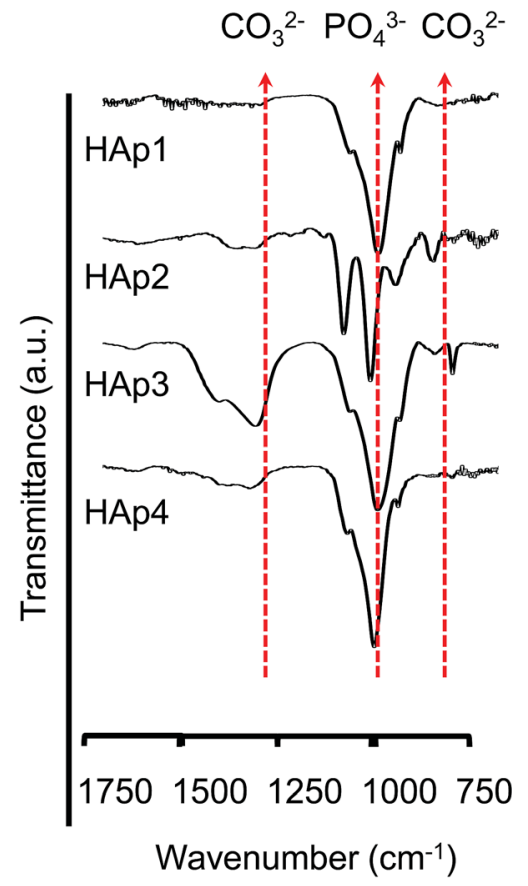

Fig. 2 FTIR spectra of the HAp particles studied in this work.

The absorption bands at $\sim 870 \mathrm{~cm}^{-1}\left(\nu_{2}\right)$ and the most intense band at $\sim 1400 \mathrm{~cm}^{-1}\left(\nu_{3}\right)$ due to $\mathrm{CO}_{3}{ }^{2-}$ reflect that this group also plays an important role in the HAp morphology. Thus, independent of the experimental conditions used for the preparation of the particles, carbonated HAp samples have been obtained in all cases. However, the HAp3 sample, in which $\nu_{2}$ and $\nu_{3}$ occur as broad doublets at $826,873 \mathrm{~cm}^{-1}$ and 1330, $1424 \mathrm{~cm}^{-1}$ (Fig. 2), respectively, shows the highest fraction of $\mathrm{CO}_{3}{ }^{2-}$. The integrated area ratio of the bands due to $\mathrm{CO}_{3}{ }^{2-}$ and $\mathrm{PO}_{4}{ }^{3-}$ groups in HAp3 is 0.75 while in the rest of the samples this ratio is smaller than 0.3 .

Characterization of four investigated particles by X-ray diffraction (Fig. 3) was focused on peaks at $33-34^{\circ} 2 \theta$, which are characteristics of the (211), (112), and (300) HAp reflections. As can be seen in Fig. 3b, the diffraction pattern of HAp2 clearly reflects the presence of other crystalline calcium phosphate forms, in addition to those characteristic of HAp. More specifically, dicalcium phosphate anhydrous $\left(\mathrm{CaHPO}_{4}\right.$; DCPA $)$ and dicalcium phosphate dihydrate $\left(\mathrm{CaHPO}_{4} \cdot 2 \mathrm{H}_{2} \mathrm{O}\right.$; DCPD) are identified in such a sample, explaining its low $\mathrm{Ca} / \mathrm{P}$ ratio. The coexistence of HAp and other calcium phases in HAp2, which has also been observed in the material precipitated from aqueous calcium phosphate solutions, has been attributed to the incomplete transformation of transient phases to HAp or to the co-precipitation of HAp with the other calcium phosphate phases. The coexistence of different calcium phosphates has been observed in vivo, also suggesting that DCPA and DCPD are intermediate phases. ${ }^{53}$ In fact the latter assumption is reinforced by the transformation of dicalcium phosphate into HAp upon immersion in synthetic body fluid solutions. ${ }^{54}$

The use of HAp particles as a non-viral gene carrier requires not only the adsorption of DNA but also the dissolution of the inorganic particles once HAp-DNA complexes have penetrated into the cell. As the latter process may be determined by the compositional and physical differences (Tables 1 and $\mathrm{S} 2 \dagger$ ),
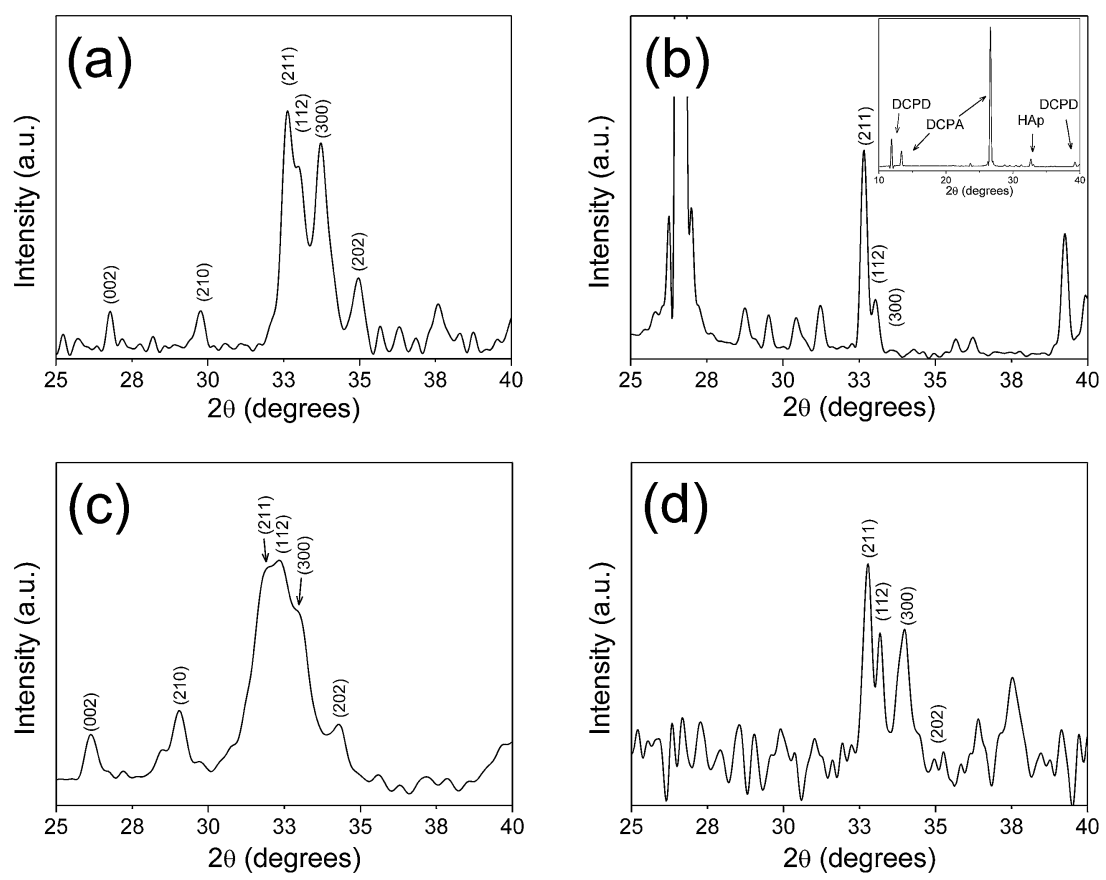

Fig. 3 X-ray diffraction patterns of the HAp particles studied in this work. Hydroxyapatite was identified by the peaks at 33-34 $2 \theta$. (a) HAp1, (b) HAp2, (c) HAp3 and (d) HAp4. The inset in (b) shows the patterns at $10-40^{\circ} 2 \theta$ to demonstrate the mixture of HAp with other calcium phosphate phases (see text). 


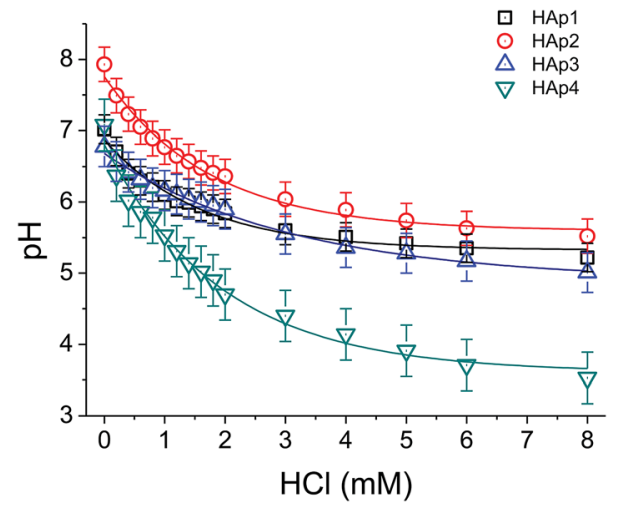

Fig. 4 Proton-buffering capacity of the HAp particles studied in this work.

investigation of the response of the four HAp particles to acidic environments is required. Titration results (Fig. 4) indicated a steep $\mathrm{pH}$ gradient for HAp4, whereas the slow and gradual variation of the $\mathrm{pH}$ evidenced a remarkable buffering effect for the rest of the samples. The exponential decay of the $\mathrm{pH}(y)$ against the concentration of $\mathrm{HCl}(x)$ for suspensions of the different particles was modeled using the following equation:

$$
y=y_{0}+A \mathrm{e}^{(-x / \tau)}
$$

where $y_{0}$ corresponds to the $\mathrm{pH}$ of the acidified suspension once stabilized, $A$ is a constant that represents the reduction of the $\mathrm{pH}$ with respect to the initial value and $\tau$ is a constant to express the $\mathrm{pH}$ exponential decay. Adjustment of the experimental data led to the parameters listed in Table S3. $\dagger$ As can be seen, the buffering effect is very low for HAp4 that shows the highest $A$ value $(3.20 \pm 0.10)$. The latter value perfectly reflects the measured $\mathrm{pH}$ reduction, $\Delta \mathrm{pH}$, from 7.08 to 3.61. HAp1 and HAp3 present the highest buffering effect with $A$ values of only $1.55 \pm 0.07$ and $1.79 \pm 0.06$, respectively, while HAp2 shows an intermediate situation (i.e. $A=2.16 \pm 0.07$ ). On the other hand, comparison of the $\tau$ values indicates that the buffering response is about two-fold faster for HAp1 than for HAp3. The summary of these results evidences that the chemical composition, especially the $\mathrm{CO}_{3}{ }^{2-} / \mathrm{PO}_{4}{ }^{3-}$ ratio, plays a major role in the proton-buffering capacity of HAp particles.

\section{Binding of plasmid DNA to HAp particles}

In order to evaluate the capacity of HAp surfaces to adsorb biomolecules, particles obtained in the previous section were incubated with plasmid DNA. Complexes were separated by centrifugation and detected by electrophoresis. Fig. 5a indicates that DNA is adsorbed onto the surface of all prepared HAp particles. However, the concentration of biomolecules adsorbed by different HAp samples, which was quantified by measuring the relative intensity of the fluorescence bands (Fig. 5b), grows with the concentration of HAp in the DNA: HAp mixture. Furthermore, DNA adsorption depends on the HAp properties, with HAp3 and HAp4 samples adsorbing more DNA than HAp1 and HAp2 (Fig. 5b). This is fully consistent with the zeta

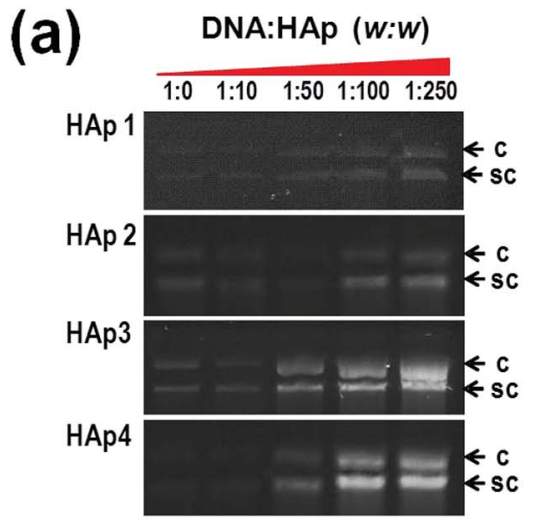

(b)

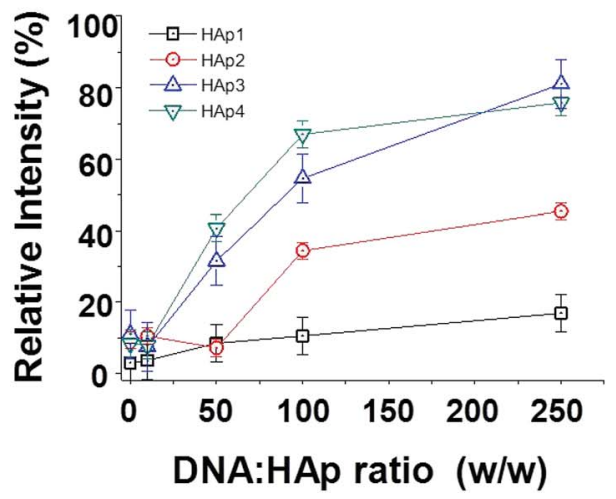

Fig. 5 DNA : HAp complexes formed by mixing pMT4 plasmid DNA and HAp1-HAp4 particles considering $1: 0,1: 10,1: 50,1: 100$ and $1: 250 \mathrm{w} / \mathrm{w}$ ratios: (a) agarose gel electrophoretograms in which circular and supercoiled conformations (c and Sc, respectively) are observed; and (b) quantification through the relative intensity of the fluorescence band of the amount of DNA adsorbed in complexes derived from mixtures with different weight ratios.

potential values displayed in Table 1 and the assumption that the surfaces of HAp2 and HAp1 particles are dominated by the negatively charged $\left(010 ; \mathrm{Ca}^{2+}-\mathrm{OH}^{-}\right)$and (001) planes, respectively. Thus, the DNA polyanions are easily adsorbed onto the amorphous and positively charged surfaces associated with HAp3 and HAp4, respectively. On the other hand, HAp1 commercial particles show linear behavior, even though the relative intensity of the fluorescence band for complexes formed using a 1 : 250 DNA : HAp mixture is relatively low ( 20\%). In contrast exponential behavior was identified for all synthesized particles, the relative intensity of the fluorescence band associated with DNA-HAp complexes derived from 1 : 250 mixtures reaching values of $\sim 40 \%$ (HAp2), $\sim 70 \%$ (HAp4) and $\sim 80 \%$ (HAp3).

The stability of DNA-HAp complexes was evaluated by examining the protection imparted by the HAp particles against the SalI restriction enzyme and DNaseI endonuclease. Sal1 cuts off the pMT4 plasmid DNA at only one restriction site while DNaseI is an unspecific endonuclease that attacks DNA independent of the sequence. The protecting activity was tested for complexes derived from DNA : HAp mixtures with 1 : 100 and 
$1: 250 \mathrm{w} / \mathrm{w}$ ratios, which showed the highest concentration of adsorbed DNA. Fig. 6a, which displays the electrophoretograms obtained after enzymatic digestion, clearly indicates that DNA receives protection against Sal1 restriction enzymes in DNAHAp complexes. Moreover, quantitative analyses of the fluorescence bands (Fig. 6b) evidence that HAp3 and HAp4 particles impart very remarkable protection since $\sim 80 \%$ of the DNA contained in both $1: 100$ and $1: 250$ complexes was preserved from Sal1. The results related to the protection imparted against unspecific DNaseI are even more exciting. Although this enzyme attacks all positions of DNA because of its unspecific activity, biomolecules adsorbed onto HAp3 and HAp4 resist considerably the aggressive action of this enzyme (Fig. 6a). Thus, $\sim 20 \%$ of DNA in DNA-HAp3 and DNA-HAp4 complexes remains protected from the digestion with DNaseI (Fig. 6c).

In order to investigate the thermal stability of the biomolecules in DNA-HAp, complexes obtained using 1:100 and $1: 250$ mixtures were subjected to a thermal denaturalization process. Fig. 7a shows that the absorbance of DNA at $260 \mathrm{~nm}$ without HAp, which was used as the control, increases by $\sim 41 \%$ (hypochromic shift) when heated to $96^{\circ} \mathrm{C}$ for $10 \mathrm{~min}$ because of the higher exposure of all nitrogen bases. Analysis of the DNA response upon heating in DNA-HAp complexes reveals three different behaviors (Fig. 7b). Nitrogen bases are highly exposed in DNA-HAp2 complexes, as is evidenced by the very large hypochromic effect. In contrast, the hypochromic shift is very low for DNA bases in complexes with HAp3 particles. This is consistent with DNA compaction and, therefore, higher resistance against thermal denaturalization. Finally, the behavior of the biomolecule in DNA-HAp1 complexes is similar to that displayed by the control while the shift found for DNA-HAp4 complexes is intermediate between those of DNA-HAp1 and DNA-HAp3. The summary of these results clearly indicates that thermal denaturalization of DNA in DNA-HAp complexes is influenced by the physical properties of mineral particles, differences being fully consistent with the response of the different complexes towards the enzymatic attack.

\section{Computer simulation of DNA adsorption onto HAp surfaces}

To understand in detail the mechanisms of interaction between HAp and DNA at the molecular level, the focus should be on the microstructure of HAp. For this purpose, we have concentrated on the most significant HAp surfaces, which are (001) and (010). More specifically, the ability to bind DNA has been modeled considering surfaces constructed using the (001) plane and both the $\left(010 ; \mathrm{Ca}^{2+}-\mathrm{OH}^{-}\right)$and $\left(010 ; \mathrm{Ca}^{2+}\right)$ terminations, which have been attributed to the HAp1, HAp2 and HAp4 samples,

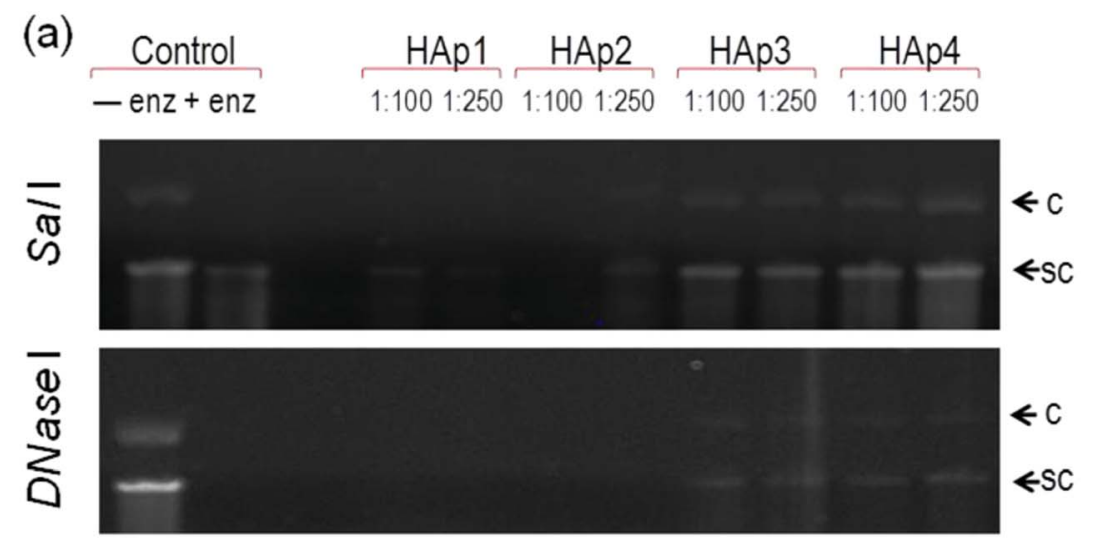

(b)

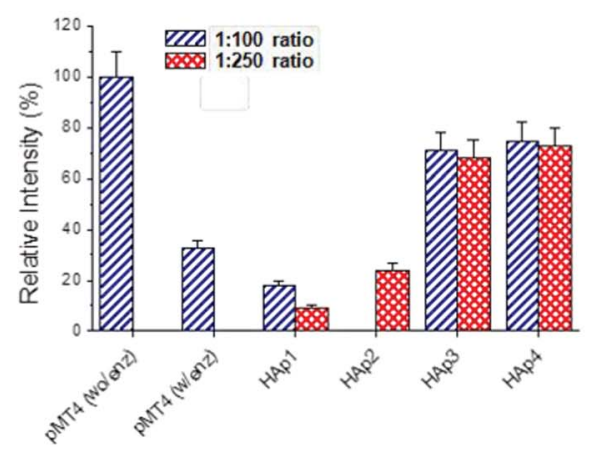

(c)

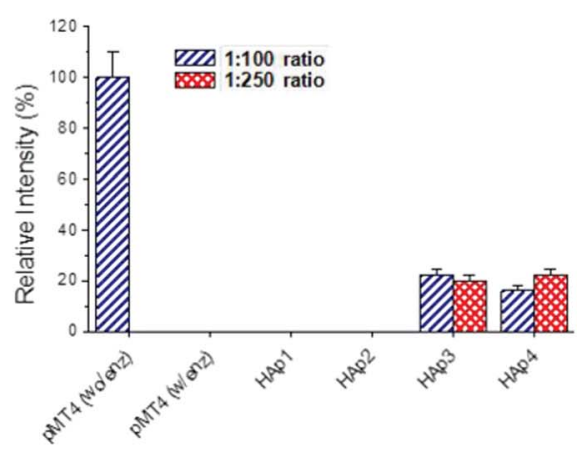

Fig. 6 Enzymatic digestion of the DNA : HAp complexes: (a) agarose gel electrophoretograms of complexes derived from $1: 100$ and $1: 250$ mixtures after digestion with Sall and DNasel. The pMT4 plasmid was used as the control in the absence of the enzyme (-enz) and digested with the enzyme (+enz); (b) quantification of DNA that remains in the complexes after digestion with Sall restriction enzyme; and (c) quantification of DNA that remains in the complexes after digestion with DNasel unspecific nuclease. 
(a)

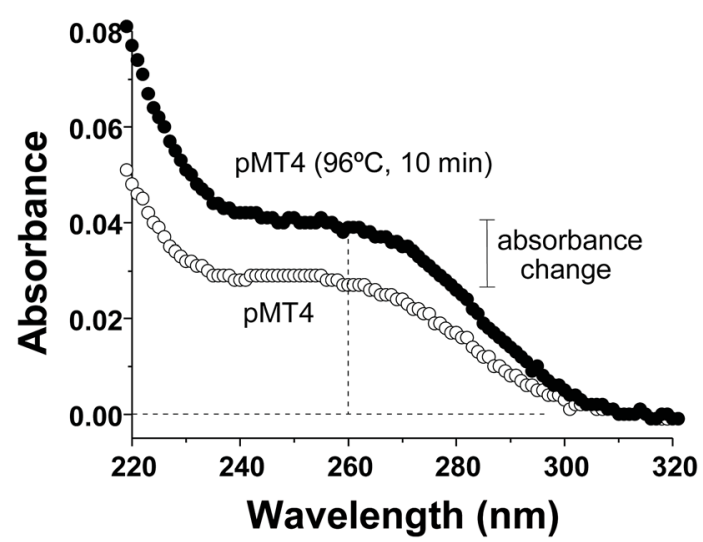

(b)

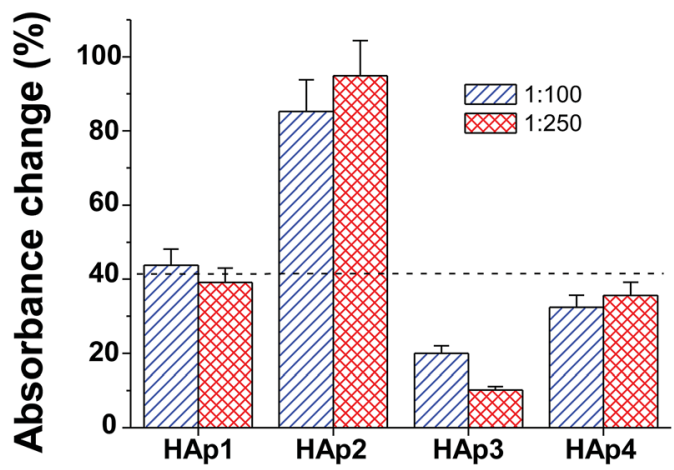

Fig. 7 Thermal denaturation of DNA in DNA-HAp complexes: (a) hypochromic effect detected upon denaturation of pMT4 plasmid by incubating at $96{ }^{\circ} \mathrm{C}$ during $10 \mathrm{~min}$; (b) absorbance change after thermal denaturation for DNA-HAp complexes derived from mixtures with $1: 100$ and $1: 250 \mathrm{w} / \mathrm{w}$ ratios. The dashed line represents the absorbance change in the pMT4 plasmid used as the control (see a).

respectively. The (010) surface with the hydroxyl channels lying parallel to the surface has been found to interact more strongly with some negatively charged species than (001). ${ }^{37}$ In spite of this, (010) is thermodynamically less stable than the (001) plane. $^{37,52}$

The DNA double helix was placed above each constructed surface and considering different starting positions. All these systems were solvated and neutralized by adding water molecules and $\mathrm{Na}^{+}$ions, respectively. After several short MD runs to thermalize and equilibrate, for each surface the most stable system was selected for production NPT-MD runs. Fig. 8 compares the initial system with the system after 15 ns of NPTMD for each surface. The response of the DNA double helix towards the (001), $\left(010 ; \mathrm{Ca}^{2+}-\mathrm{OH}^{-}\right)$and $\left(010 ; \mathrm{Ca}^{2+}\right)$ surfaces is apparently very different. Thus, the forces exerted by $\mathrm{OH}^{-}$ions of the $\left(010 ; \mathrm{Ca}^{2+}-\mathrm{OH}^{-}\right)$termination seem to induce significant structural distortions in the bound DNA double helix while such a secondary structure is preserved for the biomolecule adsorbed by the $(001)$ and $\left(010 ; \mathrm{Ca}^{2+}\right)$ surfaces.

In order to analyze this feature, representative structural parameters have been examined. Fig. 9 represents the temporal evolution of the end-to-end distance $\left(d_{\mathrm{ee}}\right)$ as the distance

\section{Initial state Final state}
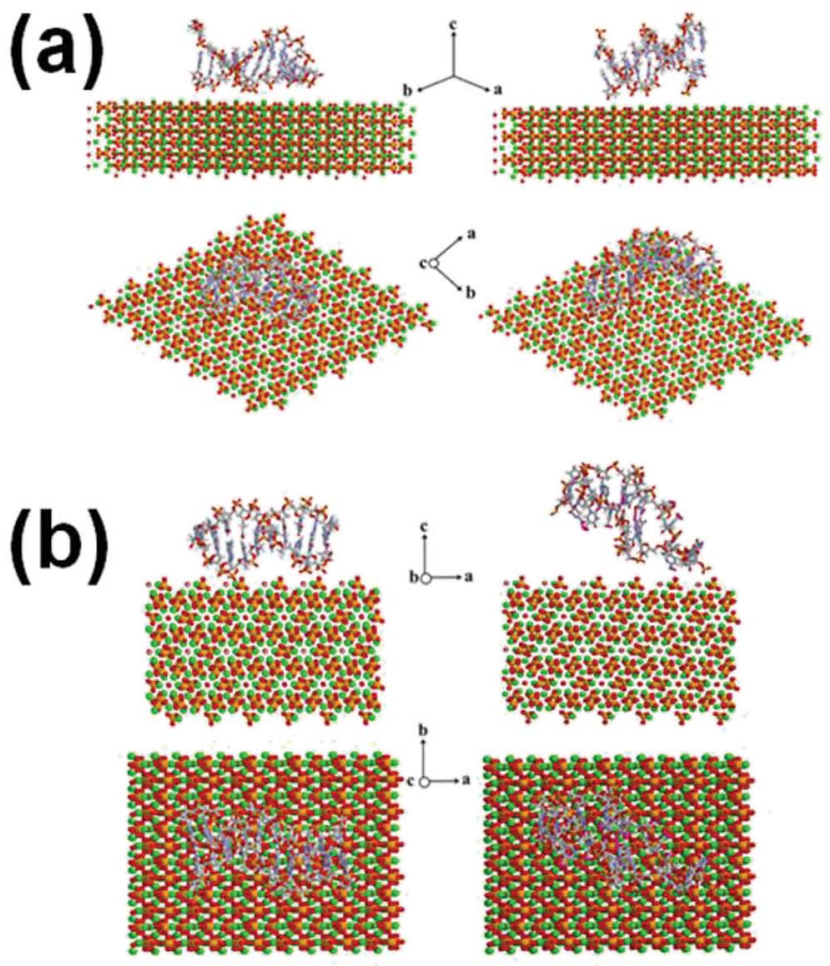

(c)
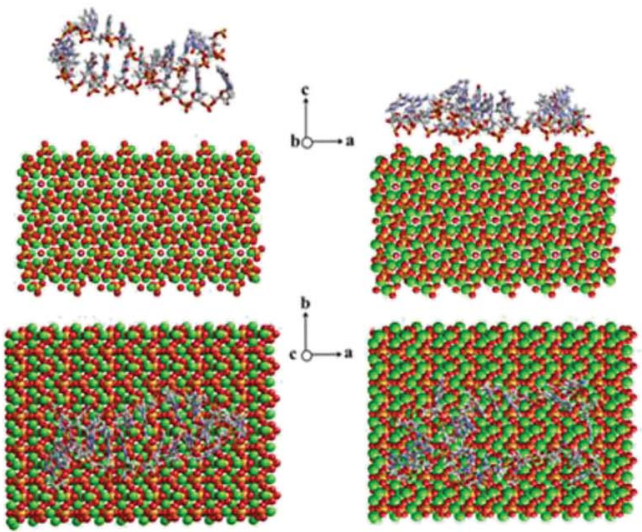

Fig. 8 Snapshots showing the double helix DNA adsorbed at the (a) (001), (b) (010; $\left.\mathrm{Ca}^{2+}-\mathrm{OH}^{-}\right)$and (c) $\left(010 ; \mathrm{Ca}^{2+}\right)$ surfaces at the beginning and end of the 15 ns NPT-MD simulations.

between the center of masses of the first and last pairs of nucleotides, the inter-strand distance $\left(D_{\mathrm{cc}}\right)$, which has been calculated as the average distance between the center of masses of each pair of nucleotides, and the root mean square deviation (RMSD) between the DNA structures adsorbed onto HAp surfaces and the canonical B-DNA double helix. Furthermore, an additional 15 ns NPT-MD simulation has been carried out considering the B-DNA double helix immersed in the simulation box full of explicit water molecules. The results, which are included in Fig. 9, have allowed us to set the upper and lower limits of variation for $d_{\mathrm{ee}}$ and $D_{\mathrm{cc}}$. Thus, these limits have been defined using standard deviation associated with the average 
values obtained for the stable B-DNA double helix in aqueous solution (i.e. without HAp).

The temporal evolution of $d_{\text {ee }}$ (Fig. 9a) for the DNA adsorbed onto the (001) surface remains within the lower and upper limits defined by DNA in solution during almost the whole trajectory. Thus, the average $d_{\mathrm{ee}}$ value for the bound biomolecule, $\left\langle d_{\mathrm{ee}}\right\rangle=30.5 \pm 1.2 \AA$, is practically identical to that obtained in solution, $\left\langle d_{\mathrm{ee}}\right\rangle=30.8 \pm 1.6 \AA$. The $d_{\mathrm{ee}}$ of the DNA adsorbed onto $\left(010 ; \mathrm{Ca}^{2+}-\mathrm{OH}^{-}\right)$exhibits significant fluctuations exceeding the upper and lower limits, as is evidenced by the large deviation associated with the average value, $\left\langle d_{\mathrm{ee}}\right\rangle=31.5 \pm 2.4 \AA$. Finally, the biomolecule experiences drastic shortening upon adsorption onto $\left(010 ; \mathrm{Ca}^{2}\right)$, stabilizing very rapidly, $\left\langle d_{\mathrm{ee}}\right\rangle=21.5 \pm 0.6 \AA$. Similar conclusions are reached by examining the temporal evolution of $D_{\mathrm{cc}}$ (Fig. 9b). The value for the DNA adsorbed onto the (001) surface remains practically constant and very close to the upper limit derived from simulations in solution. In contrast, the value for the biomolecule bound to the $\left(010 ; \mathrm{Ca}^{2+}-\mathrm{OH}^{-}\right)$shows significant fluctuations and is clearly smaller than the lower limit. The latter reduction is consistent with a loss of the secondary structure. Finally, although the adsorption onto $\left(010 ; \mathrm{Ca}^{2+}\right)$ initially provokes an expansion of the inter-strand distance, after $\sim 5 \mathrm{~ns}$ this parameter equilibrates at a value $\sim 0.4 \AA$ higher than that reached for (001). Thus, the average $D_{\text {cc }}$ values for the DNA adsorbed onto the (001), $\left(010 ; \mathrm{Ca}^{2+}-\mathrm{OH}^{-}\right)$and $\left(010 ; \mathrm{Ca}^{2+}\right)$ surfaces are $\left\langle D_{\text {cc }}\right\rangle=11.95 \pm 0.13,10.40 \pm 0.67$ and $12.33 \pm 0.53$ $\AA$, respectively. The value reached in diluted aqueous solution, $\left\langle D_{\text {cc }}\right\rangle=11.71 \pm 0.27 \AA$, is similar to that obtained for the biomolecule onto the (001) surface. Fig. 9c shows the RMSD with respect to the canonical B-DNA. The double helix is remarkably stable when the biomolecule is in solution or bound to the (001) surface with average values of $2.91 \pm 0.54$ and 3.96 $\pm 0.25 \AA$, respectively. In contrast, the RMDS increases progressively for the DNA adsorbed onto the two terminations of the (010) surface, values higher than 8 and $6 \AA$ being reached after $15 \mathrm{~ns}$ for $\left(010 ; \mathrm{Ca}^{2+}-\mathrm{OH}^{-}\right)$and $\left(010 ; \mathrm{Ca}^{2+}\right)$, respectively.

Local distortions in adsorbed DNA have been investigated by comparing the radial distribution functions of $\mathrm{P} \cdots \mathrm{P}$ pairs (where $\mathrm{P}$ refers to the phosphor atoms contained in phosphate groups of DNA), $g_{\mathrm{P}-\mathrm{P}}(r)$ (Fig. 10a), and $\mathrm{H} \cdots \mathrm{O}$ pairs (where $\mathrm{H}$ and $\mathrm{O}$ refer to the hydrogen atoms of $\mathrm{R}-\mathrm{NH}_{2}$ groups and oxygen atoms of DNA bases located at the internal side of the double helix), $g_{\mathrm{H}-\mathrm{O}}(r)$ (Fig. 10b), for the biomolecules adsorbed onto the (001), (010; $\left.\mathrm{Ca}^{2+}-\mathrm{OH}^{-}\right)$and $\left(010 ; \mathrm{Ca}^{2+}\right)$ surfaces and the biomolecule in aqueous solution. The $g_{\mathrm{P}-\mathrm{P}}(r)$ profile calculated for the DNA in solution shows a sharp bimodal peak centered at $r=6.4$ and $7.0 \AA$ that is enhanced for the biomolecule adsorbed onto the (001) surface. However, the peak of the profile calculated for $\left(010 ; \mathrm{Ca}^{2+}-\mathrm{OH}^{-}\right)$becomes smaller and broader, suggesting some type of short-range deformations at the DNA backbone. The biomolecule adsorbed onto $\left(010 ; \mathrm{Ca}^{2+}\right)$ also (a)

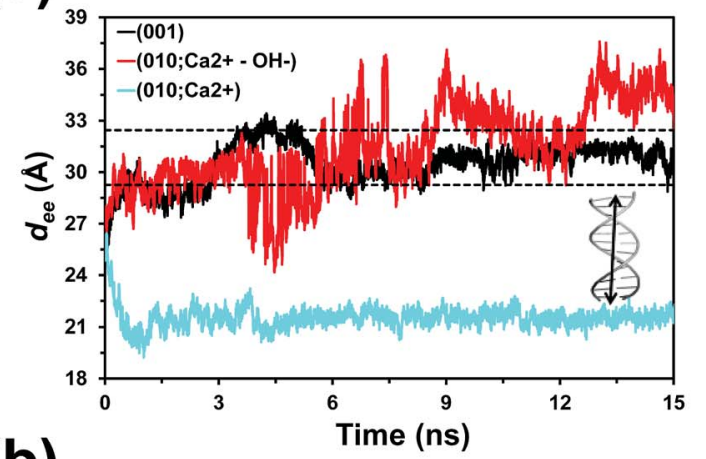

(b)

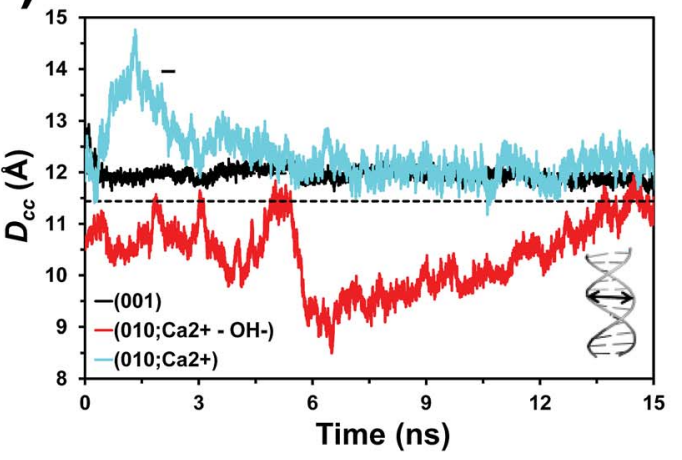

(c)

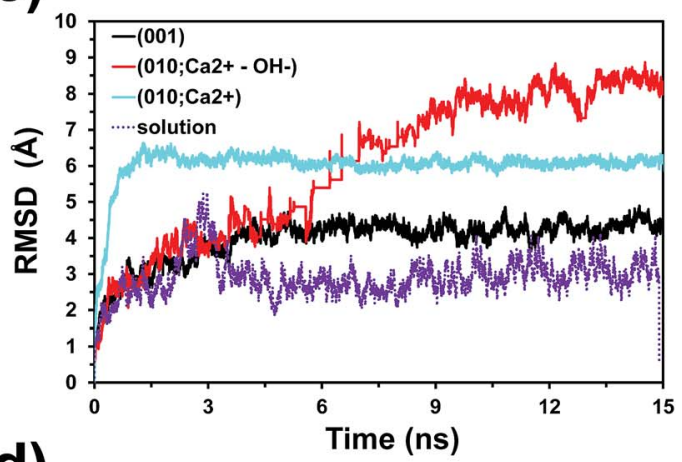

(d)

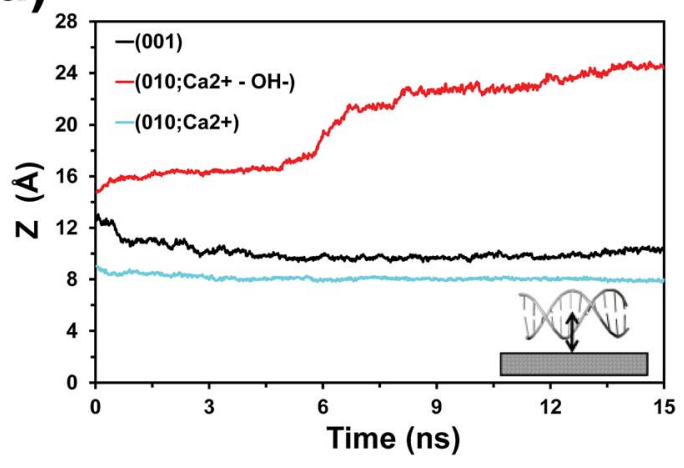

Fig. 9 Temporal evolution of (a) the end-to-end distance, $d_{\mathrm{ee}}$, the (b) inter-strand distance, $D_{\mathrm{cc}}$, (c) the root mean square deviation, RMSD, with respect to the canonical B-DNA double helix, and (d) the distance between the center of mass of the double helix and the HAp, expressed as the $z$-coordinate of the normal vector to the surface, $Z$, for DNA adsorbed onto the (001), $\left(010 ; \mathrm{Ca}^{2+}-\mathrm{OH}^{-}\right)$and $\left(010 ; \mathrm{Ca}^{2+}\right)$ surfaces. Upper and lower limits for the $d_{\mathrm{ee}}$ and $D_{\mathrm{cc}} \mathrm{B}-\mathrm{DNA}$ double helix, which were estimated from a $15 \mathrm{~ns}$ MD simulation in solution, are represented in (a) and (b) using dashed lines. The RMSD obtained for the DNA in solution has been included in (c). 
(a)

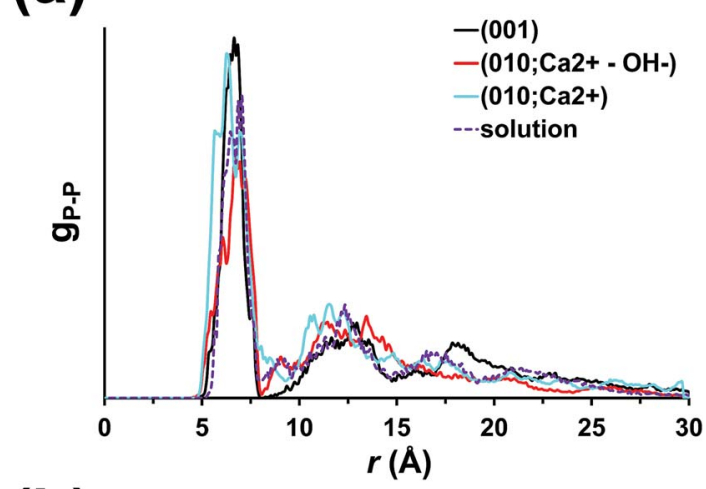

(b)

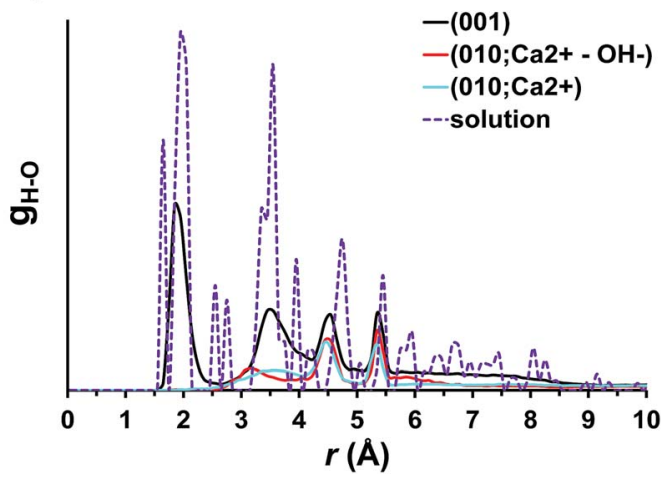

Fig. 10 Radial distribution functions of (a) $\mathrm{P} \ldots \mathrm{P}$ and (b) $\mathrm{H} \cdots \mathrm{O}$ atom pairs for the DNA double helix adsorbed onto the (001), (010; $\left.\mathrm{Ca}^{2+}-\mathrm{OH}^{-}\right)$and $\left(010 ; \mathrm{Ca}^{2+}\right)$ surfaces, and immersed in water. P refers to the phosphor atoms of the phosphate groups at the DNA backbone, whereas $\mathrm{H}$ and $\mathrm{O}$ correspond to the hydrogen atoms of $\mathrm{NH}_{2}$ groups and oxygen atoms of DNA bases located at the internal side of the double helix.

deviates from the in solution behavior, even though differences are considerably less pronounced than for $\left(010 ; \mathrm{Ca}^{2+}-\mathrm{OH}^{-}\right)$. These local distortions affect inter-strand hydrogen bonding interactions, which are essential to retain the secondary structure. Thus, $g_{\mathrm{H}-\mathrm{O}}(r)$ calculated for the DNA in solution clearly indicates a large number of sharp and narrow peaks, the one centered at $r=1.9 \AA$ being associated with hydrogen bonds between complementary bases. This peak is clearly identified in the profile calculated for the DNA adsorbed onto the (001) surface but it disappears when the biomolecule is deposited onto the two terminations of the (010) surface. Thus, the first peak detected for $\left(010 ; \mathrm{Ca}^{2+}-\mathrm{OH}^{-}\right)$and $\left(010 ; \mathrm{Ca}^{2+}\right)$ is centered at $r=3.2$ and $3.5 \AA$, respectively, indicating that the accumulation of local distortions provokes the loss of the secondary structure evidenced in Fig. 8 and 9.

Snapshots at the end of the MD trajectories (Fig. 11) suggest that the DNA on the $\left(010 ; \mathrm{Ca}^{2+}-\mathrm{OH}^{-}\right)$surface is only partially adsorbed (i.e. one of the double helix extremes fluctuates freely) while the biomolecule is completely adsorbed onto the (001) and $\left(010 ; \mathrm{Ca}^{2+}\right)$ planes because of the higher number of interaction sites. Fig. 9d represents the temporal evolution of the distance between the center of mass of the DNA double helix

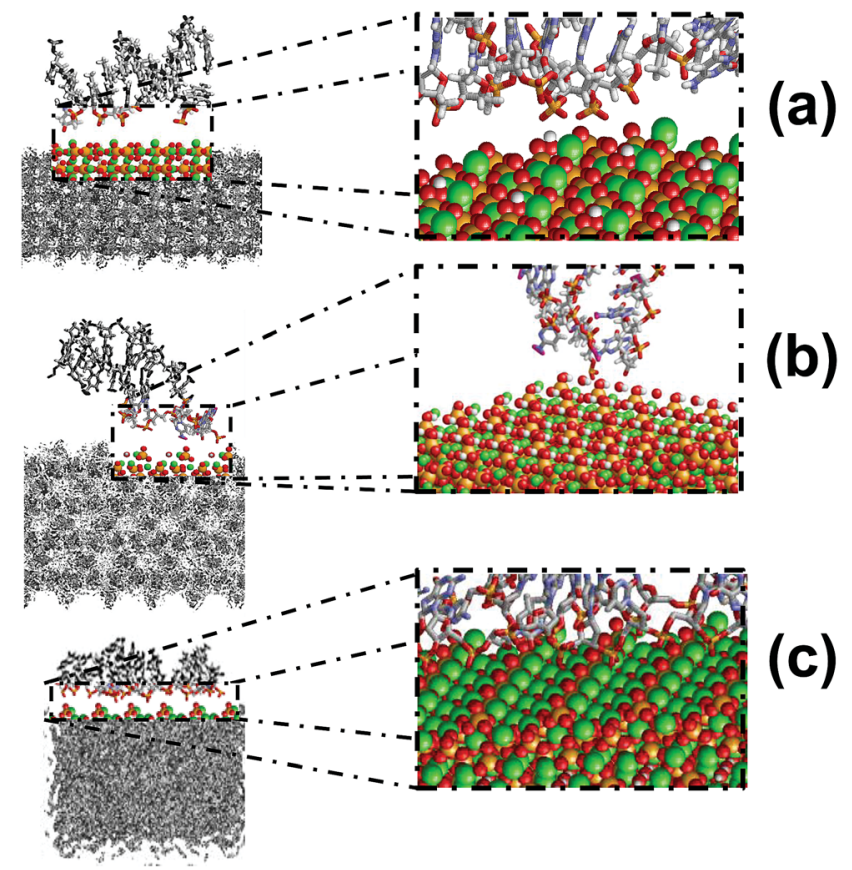

Fig. 11 Snapshots showing details of: (a) the attractive $\mathrm{Ca}^{2+}$ (surface) $\cdots$ phosphate(DNA) interactions at the (001) surface; (b) the repulsive $\mathrm{OH}^{-}$(surface) $\cdots$ phosphate(DNA) interactions at the $\left(010 ; \mathrm{Ca}^{2+}-\mathrm{OH}^{-}\right.$) surface; and the attractive $\mathrm{Ca}^{2+}$ (surface) $\cdots$ phosphate(DNA) interactions at the $\left(010 ; \mathrm{Ca}^{2+}\right)$ surface.

and HAp, expressed as the $z$-coordinate of the normal vector to the surface $(Z)$, for the three simulated systems. As can be seen, after thermalization and equilibration trajectories the parameter $Z$ at the beginning of the production trajectory was 12.6, 14.7 and $9.0 \AA$ for $(001),\left(010 ; \mathrm{Ca}^{2+}-\mathrm{OH}^{-}\right)$and $\left(010 ; \mathrm{Ca}^{2+}\right)$, respectively. For the former surfaces $Z$ decreases to $\sim 10 \AA$ in $\sim 2.5 \mathrm{~ns}$ while for $\left(010 ; \mathrm{Ca}^{2+}\right)$ it decreases to $\sim 8 \AA$ in $\sim 5 \mathrm{~ns}$, stabilizing at such values. The average value considering the last $10 \mathrm{~ns}$ of production trajectory is $\langle Z\rangle=9.85 \pm 0.25$ and $8.02 \pm$ $0.09 \AA$ for $(001)$ and $\left(010 ; \mathrm{Ca}^{2+}\right)$, respectively. This feature indicates that the re-arrangements in the DNA double helix (Fig. 8) are accompanied by an enhancement of the binding to the surface. In opposition, for $\left(010 ; \mathrm{Ca}^{2+}-\mathrm{OH}^{-}\right) Z$ progressively increases from 14.7 to $\sim 16.5 \AA$ in the first 5 ns of trajectory, the latter value increasing in only $1.5 \mathrm{~ns}$ to $\sim 21.5 \AA$. Finally, in the last $7 \mathrm{~ns}$ of trajectory, $Z$ increases slowly but progressively from $\sim 22.8$ to $24.5 \AA$ A. This profile indicates that, actually, DNA is slowly released from the $\left(010 ; \mathrm{Ca}^{2+}-\mathrm{OH}^{-}\right)$surface undergoing a desorption process.

The binding energy $\left(E_{\text {bind }}\right)$ associated with the adsorption of a DNA molecule to the HAp surface was roughly estimated as the sum of the electrostatic and van der Waals contributions from DNA $\cdots$ surface interactions ( $E_{\text {ele }}$ and $E_{\mathrm{vdw}}$, respectively). The average energy contributions obtained for the biomolecule adsorbed onto the (001) surface are $\left\langle E_{\text {bind }}\right\rangle=-8508 \pm 251 \mathrm{kcal}$ $\mathrm{mol}^{-1},\left\langle E_{\text {ele }}\right\rangle=-8497 \pm 252 \mathrm{kcal} \mathrm{mol}^{-1}$ and $\left\langle E_{\mathrm{vdw}}\right\rangle=-11 \pm 3$ kcal $\mathrm{mol}^{-1}$, indicating that the adsorption of DNA to this surface is thermodynamically favorable. This process is energetically favored by the stabilizing surface $\cdots$ DNA electrostatic 
contribution, which is essentially due to the attractive $\mathrm{Ca}^{2+}$ (surface) $\cdots$ phosphate(DNA) interactions (Fig. 11a). The strength of the interaction between the adsorbed biomolecules and the $\left(010 ; \mathrm{Ca}^{2+}\right)$ surface is almost three times more attractive: with $\left\langle E_{\text {bind }}\right\rangle=-21561 \pm 473 \mathrm{kcal} \mathrm{mol}^{-1},\left\langle E_{\text {ele }}\right\rangle=-21518 \pm 467$ kcal $\mathrm{mol}^{-1}$ and $\left\langle E_{\mathrm{vdw}}\right\rangle=-43 \pm 6 \mathrm{kcal} \mathrm{mol}^{-1}$. This has been attributed to the disposition of the $\mathrm{Ca}^{2+}$ ions, which act as binding sites, very suitable to interact with the phosphate(DNA) groups once the double helix undergoes deformation (Fig. 11c). In contrast, the average values obtained for the DNA adsorbed onto the $\left(010 ; \mathrm{Ca}^{2+}-\mathrm{OH}^{-}\right)$surface clearly reflect a repulsive process, which is fully consistent with the structural results and desorption process discussed above: $\left\langle E_{\text {bind }}\right\rangle=10825 \pm 37 \mathrm{kcal}$ $\mathrm{mol}^{-1},\left\langle E_{\text {ele }}\right\rangle=10868 \pm 44 \mathrm{kcal} \mathrm{mol}^{-1}$ and $\left\langle E_{\mathrm{vdw}}\right\rangle=-43 \pm 9$ kcal mol ${ }^{-1}$. The poor affinity of DNA towards $\left(010 ; \mathrm{Ca}^{2+}-\mathrm{OH}^{-}\right)$is due to the disposition of the negatively charged hydroxyl group, which interacts repulsively with the DNA phosphate groups. This is clearly evidenced in Fig. 11b, which displays the disposition of the surface hydroxyl groups shielding the attractive interactions $\mathrm{Ca}^{2+}$ (surface) $\cdots$ phosphate(DNA). The role of the van der Waals interactions is practically negligible for the surfaces constructed using the two terminations of the (010) plane, the importance of the electrostatic contribution being noticeably higher than that reported for DNA strands deposited on other kinds of surfaces, as for example gold ${ }^{55}$ and carbon nanotubes. ${ }^{56}$

These results are fully consistent with experimental data discussed above, which evidenced very different sensitivities of the prepared HAp samples towards DNA adsorption. It is wellknown that HAp surfaces are responsible for the crystal morphology. Synthetic HAp crystals are often facetted with the possible six equivalent faces related to the (001) surface in hexagonal symmetry. ${ }^{57}$ All these faces have been reported to adsorb negatively charged carboxylate groups. ${ }^{55}$ This behavior is in agreement with the affinity of HAp1 towards DNA. Thus, the surface charge and surface $\mathrm{Ca} / \mathrm{P}$ ratio are consistent with the predominance of (001) planes in semicrystalline commercial HAp1 samples. It is possible to grow highly crystalline HAp particles with platelet morphology exposing the (010) planes as basal surfaces, and (001) and (100) as lateral terminations. ${ }^{58}$ Morphological and physical properties (Fig. 1 and Table 1, respectively) suggest that (010) is the most abundant place in HAp2 and HAp4, the difference between the two samples being attributed to the facet termination. The (010) plane was found to adsorb glycine amino acid, through both the $\mathrm{N}$ atom and the negatively charged $\mathrm{COO}^{-}$group. ${ }^{49}$ de Leeuw and co-workers ${ }^{37}$ studied the interaction of (010) HAp surfaces with glycine, proline and hydroxyproline amino acids, which are major constituents of the collagen I protein. The results revealed that interactions involving the hydrogen atoms attached to the nitrogen of amine and the oxygen atoms belonging to the surface hydroxyl and phosphate groups play a decisive role in the binding of these amino acids to the $\left(010 ; \mathrm{Ca}^{2+}-\mathrm{OH}^{-}\right)$ termination of this surface. ${ }^{37}$ It is worth noting that $\mathrm{N}-\mathrm{H}$ and $\mathrm{N}-\mathrm{H}_{2}$ groups belonging to the DNA bases are less accessible than the backbone phosphate groups because of the formation of interstrand hydrogen bonds through base pairing. Accordingly, adsorption of double stranded DNA onto $\left(010 ; \mathrm{Ca}^{2+}\right)$ is a very favorable process while it is disfavored when termination of the surface corresponds to $\left(010 ; \mathrm{Ca}^{2+}-\mathrm{OH}^{-}\right)$. These results are in excellent agreement not only with the DNA adsorption abilities determined for HAp2 and HAp4 (Fig. 5b) but also with protection imparted by these particles to the adsorbed DNA (Fig. 6 and 7). Accordingly, simulation results discussed in this section explain at the molecular level our previously discussed experimental observations, which evidenced that HAp properties affect not only the DNA adsorption ability but also the protection imparted to the biomolecule upon the attack of nucleases and thermal denaturalization.

\section{Transfection of pMT4-HAp complexes into $E$. coli}

In order to evaluate the efficacy of the different HAp particles as vectors for transfection processes, plasmid DNA was introduced and amplified into E. coli bacteria. pMT4 contains an ampicillin resistance gene that is commonly used as a selectable marker in routine biotechnology. A heat shock protocol was applied to transfect centrifuged DNA-HAp complexes into competent bacteria, which were subsequently seeded into ampicillin-containing LB agar plates. Growth of the seeded colonies was observed after 16-24 $\mathrm{h}$ indicating that the fluidity of bacteria membranes was changed by the created temperature unbalance $\left(42{ }^{\circ} \mathrm{C} \times 2 \mathrm{~min}\right.$ ), enabling the entry of DNA-HAp complexes. Internalized complexes form endosomes, endosomal escape of DNA depending on the proton buffering capacity of the different HAp particles. Thus, the $\mathrm{pH}$ of the endosomes decreased to 5 with time, provoking the disintegration and release of their components. Colonies were subsequently cultured in the LB plate to promote plasmid DNA amplification. Fig. 12 shows purified plasmid DNA extracted from these cultures, the intensity of the bands being related to the transfection efficiency. As can be seen, DNA bands derived from complexes with HAp2 and HAp4 are weak while bands obtained using HAp1 and HAp3 complexes show intensities similar to the control.

Results displayed in Fig. 12 do not allow us to establish a direct relationship between the transfection efficiency and the amount of plasmid DNA adsorbed on HAp particles (Fig. 5b) or the protection imparted by HAp particles against enzymes (Fig. 6b and c). However, comparison between results reported in Fig. 4 and 12 suggests that the response of HAp particles

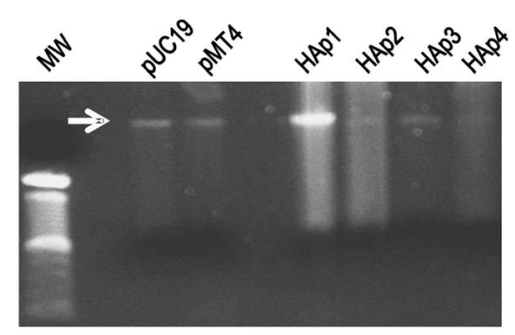

Fig. 12 Agarose gel electrophoretograms showing the transformation of $E$. coli DH5 $\alpha$ with the DNA : HAp complexes. The arrows indicate the purified pMT4 after the culture of transformed bacteria. 
towards an acidic medium exerts a decisive influence on the transfection process. Thus, HAp1 and HAp3 present the highest proton-buffering capacity (Table S3†).

\section{Conclusions}

HAp particles with different morphologies and compositions have been prepared by modifying the experimental conditions used in the chemical precipitation process. The surfaces of these particles, which differ in the zeta potential (i.e. surface charge) and in the $\mathrm{Ca} / \mathrm{P}$ ratio, show different abilities to adsorb DNA and protect the biomolecule towards nucleases. Structural changes induced in plasmid DNA during the adsorption process result in an increment of the resistance against enzymatic digestion. On the basis of their properties, the surface of HAp1, HAp2 and HAp4 crystalline particles has been assumed to be dominated by the (001), $\left(010 ; \mathrm{Ca}^{2+}-\mathrm{OH}^{-}\right)$and $\left(010 ; \mathrm{Ca}^{2+}\right)$ planes, respectively. Atomistic computer simulations have been used to explain the influence of the HAp surface on the binding process and stability of the DNA conformation. The binding is favorable for the (001) surface which allows maintaining the B-DNA double helix conformation. In contrast, the binding is disfavored for $\left(010 ; \mathrm{Ca}^{2+}-\mathrm{OH}^{-}\right)$with repulsive interactions provoking structural deformations in the DNA. The termination of the (010) surface with $\mathrm{Ca}^{2+}$ and $\mathrm{PO}_{4}{ }^{3-}$ ions $\left(010 ; \mathrm{Ca}^{2+}\right)$ adsorbs the biomolecule through very strong attractive interactions, even though the double helix undergoes structural distortions. On the other hand, the $\mathrm{CO}_{3}{ }^{2-} / \mathrm{PO}_{4}{ }^{3-}$ ratio has been found to be responsible for different buffering capacities of HAp particles. Finally, transformation assays evidence that DNA-HAp complexes prepared in this work can be used as non-viral gene carriers. The summary of the results indicates that physical properties and composition of HAp play a crucial role in the ability to adsorb DNA while the buffering activity is essential for the transfection process.

\section{Acknowledgements}

This work was supported by B. Braun Surgical S.A. through a joint research agreement with UPC. Special thanks to $\mathrm{Mr}$ M. Jiménez for supporting the idea. This work is integrated within a wider research project supported by B. Braun Surgical S.A., UPC, Institut de Ciencies Fotòniques (ICFO), and the Institut Català de la Salut (ICS) through the H. U. Germans Trias I Pujol and H. U. Vall d'Hebron, MICINN-FEDER funds (MAT201234498 and MAT2012-36205), and by the Generalitat de Catalunya (2009SGR925, 2009SGR1208 and XRQTC). Authors are indebted to the Centre de Supercomputació de Catalunya (CESCA) for computational facilities. Support for the research of C.A. was received through the "ICREA Academia".

\section{References}

1 H. Dietz, S. M. Douglas and W. M. Shih, Science, 2009, 325, 725-730.

2 N. Stephanopoulos, M. Liu, G. J. Tong, Z. Li, Y. Liu, H. Yan and M. B. Francis, Nano Lett., 2010, 10, 2714-2720.
3 E. Winfree, F. Liu, L. A. Wenzler and N. C. Seeman, Nature, 1998, 394, 539-544.

4 C. Zhang, C. Tian, F. Guo, Z. Liu, W. Jiang and C. Mao, Angew. Chem., Int. Ed., 2012, 51, 3382-3385.

5 R. P. Goodman, I. A. T. Schaap, C. F. Tardin, C. M. Erben, R. M. Berry, C. F. Schmidt and A. J. Turberfield, Science, 2005, 310, 1661-1665.

6 M. J. Glimcher, in Metabolic Bone Disease and Clinically Related Disorders, ed. L. V. Avioli and S. M. Krane, Academic Press, New York, 1998, pp. 23-50.

7 L. L. Hench, Science, 1980, 208, 826-831.

8 L. L. Hench and J. Wilson, Science, 1984, 226, 630-636.

9 Q. Fu, E. Saiz, M. N. Rahaman and A. P. Tomsia, Adv. Funct. Mater., 2013, 23, 5461-5476.

10 S. Bose, G. Fielding, S. Tarafder and A. Bandyopadhyay, Trends Biotechnol., 2013, 31, 594-605.

11 M. Bohner, Mater. Today, 2010, 13, 24-30.

12 H. Roussiere, F. Fayon, B. Alonso, T. Rouillon, V. Schnitzler, E. Verron, J. Guicheux, M. Petit, D. Massiot, P. Janvier, J. M. Bouler and B. Bujoli, Chem. Mater., 2008, 20, 182-191.

13 L. Galea, M. Bohner, J. Thuering, N. Doebelin, C. G. Aneziris and T. Graule, Biomaterials, 2013, 34, 6388-6401.

14 J. T. Zhang, W. Z. Liu, V. Schnitzler, F. Tancret and J. M. Bouler, Acta Biomater., 2014, 10, 1035-1049.

15 V. Schitzler, F. Fayon, C. Despas, I. Khairoun, C. Mellier, T. Rouillon, D. Massiot, A. Walcarius, P. Janvier, O. Gauthir, G. Montavon, J. M. Bouler and B. Bujoli, Acta Biomater., 2011, 7, 759-770.

16 G. Revilla-López, J. Casanovas, O. Bertran, P. Turon, J. Puiggalí and C. Alemán, Biointerphases, 2013, 8, 10.

17 T. Takeshita, Y. Matsuura, S. Arakawa and M. Okamoto, Langmuir, 2013, 29, 11975-11981.

18 K. B. Vasconcellos, S. M. McHugh, K. J. Dapsis, A. R. Petty and A. E. Gerdon, J. Nanopart. Res., 2013, 15, 1942.

19 O. Bertran, L. J. del Valle, G. Revilla-López, G. Chaves, L. Cardus, M. T. Casas, J. Casanovas, P. Turon, J. Puiggalí and C. Alemán, Dalton Trans., 2014, 43, 317-327.

20 M. Okazaki, Y. Yoshida, S. Yamaguchi, M. Kaneno and J. C. Elliot, Biomaterials, 2001, 22, 2459-2464.

21 V. Uskokovic and D. P. Uskokovic, J. Biomed. Mater. Res., Part $B, 2011,96,152-191$.

22 D. Olton, J. Li, M. E. Wilson, T. Rogers, J. Close, L. Huang, N. P. Kumta and C. Sfeir, Biomaterials, 2007, 28, 1267-1279.

23 R. Gonzalez-McQuire, D. W. Green, K. A. Partridge, R. O. C. Oreffo, S. Mann and S. A. Davis, Adv. Mater., 2007, 19, 2236-2240.

24 A. Maitra, Expert Rev. Mol. Diagn., 2005, 5, 893-905.

25 M. Epple, K. Ganesan, R. Heumann, J. Klesing, A. Kovtun, S. Neumann and V. Sokolova, J. Mater. Chem., 2010, 20, 18-23.

26 V. Sokolova and M. Epple, Angew.Chem., Int.Ed., 2008, 47, 1382-1395.

27 R. G. Keil, D. B. Montlucon, F. G. Prahl and J. I. Hedges, Nature, 1994, 370, 549-552.

28 J. P. Ferris, Elements, 2005, 1, 145-149.

29 M. G. Lorenz and W. Wackernagel, Microbiol. Rev., 1994, 58, 563-602. 
30 G. Romanowski, M. G. Lorenz and W. Wackernagel, Appl. Environ. Microbiol., 1991, 57, 1057-1061.

31 G. Bernardi, Nature, 1965, 206, 779-783.

32 M. Brundin, D. Figdor, G. Sundqvist and U. Sjögren, J. Endod., 2013, 39, 211-216.

$33 \mathrm{H}$. Klug and L. Alexander, in X-Ray Diffraction Procedure for Polycrystallite and Amorphous Materials, John Wiley and Sons, New York, 2nd. edn, 1974.

34 E. Landi, A. Tampieri, G. Celotti and S. Sprio, J. Eur. Ceram. Soc., 2000, 20, 2377-2387.

35 K. Grzeskowiak, D. S. Goodsell, M. Kaczor-Grzeskowiak, D. Cascio and R. E. Dickerson, Biochemistry, 1993, 32, 8923-8931.

36 L. Stork, P. Muller, R. Dronskowski and J. R. Ortlepp, Z. Kristallogr., 2005, 220, 201-205.

37 N. Almora-Barrios, K. F. Austen and N. H. de Leeuw, Langmuir, 2009, 25, 5018-5025.

38 N. H. de Leeuw, Chem. Commun., 2001, 1646-1647.

39 J. C. Phillips, R. Braun, W. Wang, J. Gumbart, E. Tajkhorshid, E. Villa, C. Chipot, R. D. Skeel, L. Kale and K. Schulten, J. Comput. Chem., 2005, 26, 1781-1802.

40 W. D. Cornell, P. Cieplak, C. I. Bayly, I. R. Gould, K. M. Merz, D. M. Ferguson, D. C. Spellmeyer, T. Fox, J. W. Caldwell and P. A. Kollman, J. Am. Chem. Soc., 1995, 117, 5179-5197.

41 Y. Duan, S. Chowdhury, M. C. Lee, G. Xiong, W. Zhang, R. Yang, P. Cieplak, R. Luo, T. Lee, J. Caldwell, J. Wang and P. A. Kollman, J. Comput. Chem., 2003, 24, 1999-2012.

42 V. Hornak, R. Abel, A. Okur, B. Strockbine, A. Roitberg and C. Simmerling, Proteins, 2006, 65, 712-725.

43 G. M. Bradbrook, T. Gleichmann, S. J. Harrop, J. Habash, J. Raftery, J. Kalb, J. Yariv, I. H. Hillier and J. R. Helliwell, J. Chem. Soc., Faraday Trans., 1998, 94, 1603-1611.
44 W. L. Jorgensen, J. Chandrasekhar, J. D. Madura, R. W. Impey and M. L. Klein, J. Chem. Phys., 1983, 79, 926935.

45 H. J. C. Berendsen, J. P. M. Postma, W. F. van Gunsteren, A. DiNola and J. R. Haak, J. Chem. Phys., 1984, 81, 3684-3690.

46 T. Darden, D. York and L. Pedersen, J. Chem. Phys., 1993, 98, 10089-10092.

47 J. P. Ryckaert, G. Ciccotti and H. J. C. Berendsen, J. Comput. Phys., 1977, 23, 327-341.

48 D. Mkhonto and N. H. de Leeuw, J. Mater. Chem., 2002, 12, 2633-2642.

49 J. Kirkham, S. J. Brookes, R. C. Shore, S. R. Wood, D. A. Smith, J. Zhang, H. Chen and C. Robinson, Curr. Opin. Colloid Interface Sci., 2002, 7, 124-132.

50 J. P. Simmer and A. G. Fincham, Crit. Rev. Oral Biol. Med., 1995, 6, 84-108.

51 J. Kirkham, S. J. Brookes, R. C. Shore, S. R. Wood, D. A. Smith, J. Zhang, H. Chen and C. Robinson, Curr. Opin. Colloid Interface Sci., 2002, 7, 124-132.

52 D. Magne, P. Pilet, P. Weiss and G. Daculsi, Bone, 2001, 29, 547-552.

53 I. A. Karampas and C. G. Kontovannis, Vib. Spectrosc., 2013, 64, 126-133.

54 S. Mandel and A. C. Tas, Mater. Sci. Eng., C, 2010, 30, 245254.

55 H. Liang, Z. Li and J. Yang, Phys. Chem. Chem. Phys., 2010, 12, 4431-4434.

56 M. V. Karachevtsev, G. O. Gladchenko, A. M. Plokhootnichenko, V. S. Leontiev and V. A. Karachevtsev, J. Phys. Chem. B, 2013, 117, 2636-2644.

57 K. Sato, Top. Curr. Chem., 2007, 270, 127-153.

58 Y. Sakhno, L. Bertinetti, M. Iafisco, A. Tampieri, N. Roveri and G. Martra, J. Phys. Chem. C, 2010, 114, 16640-16648. 